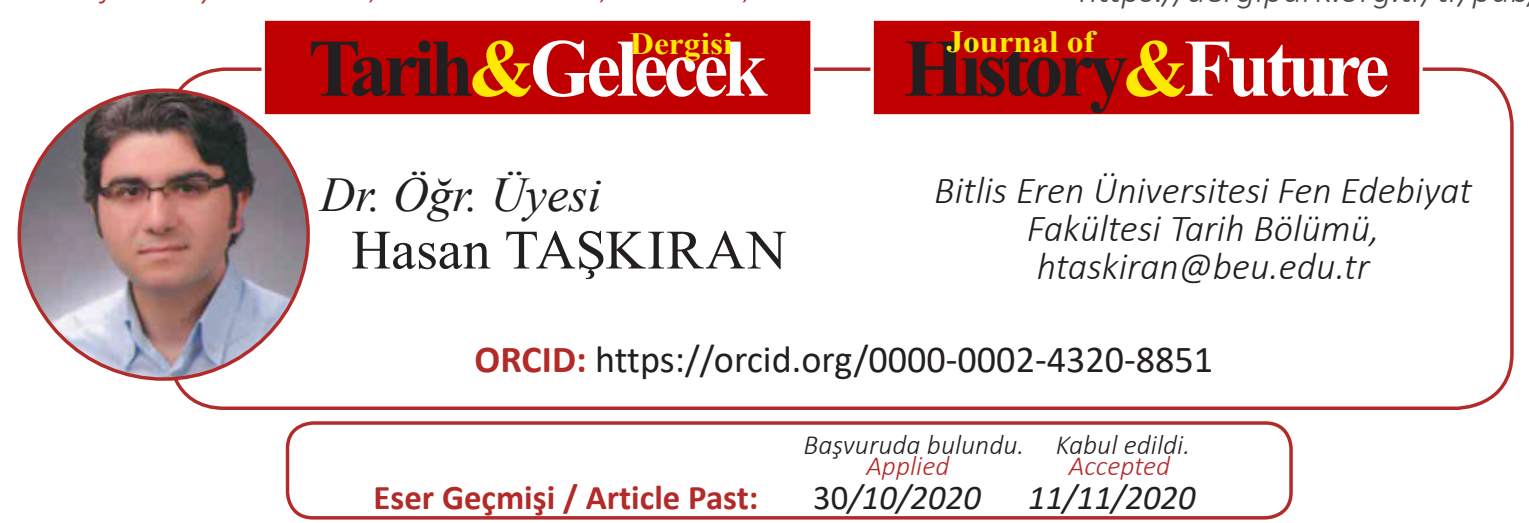

Araştırma Makalesi

DOI: http://dx.doi.org/10.21551/jhf.818784

Research Paper

Orjinal Makale / Orginal Paper

\title{
XV. Asırda Bitlis ve Çevresinin Siyasi Tarihi*
}

\section{The Political History of Bitlis and its Surroundings in the XVth Century}

\section{Öz}

Bitlis, önemli ticaret geçiş noktasında bulunan stratejik bir yerdi. Tarih boyunca birçok uygarlığa ve devlete ev sahipliği yaptı. Bu özelliğinden dolayı bölgede sürekli hâkimiyet mücadeleleri yaşanmıştı. Özellikle Rojki Emirliği, Timurlu-Kara Koyunlu ve Kara KoyunluAkkoyunlular XV. Asırda Bitlis'e hâkim olmaya çalışmışlardı. Rojki Emirleri, çatışmaları Bitlis’ten uzaklaştırmak için Timurlulara tabii oldu. Ancak Timurlular bölgeden çekildikleri zaman kent üzerinde Kara Koyunlular etkili oldu. Rojki Emirlerinden Şemseddin, Bitlis'in Karakoyunluların akınlarından korumak için Kara Yusuf'un kızıyla evlendi. Bunun yanında Van Gölü havzasını ele geçirmeleri hususunda Karakoyunlulara yardım etti. Bitlis Emirleriyle Kara Koyunlu ilişkisi, Kara Yusuf'un evlatları zamanında çatışma ekseninde devam etti. Bu çatışmaların temel sebebi Timurlular Kara Koyunlular üzerine sefere çıkınca Bitlis Emirlerinin Timurlulara bağlanmasıydı. Akkoyunlular bölgesel bir güç olunca Bitlis Emirliği, Kara Koyunlu ile Akkoyunlu mücadelesi arasında kaldı. Bu mücadeleler Bitlis Emirlerinin yanı sıra yörede yaşayan Müslüman ve Gayrimüslim halkı da derinden etkilemekteydi. Bu çalışma, XV. yüzyılda Bitlis ve çevresinde devletlerin hâkimiyet mücadelelerinin Bitlis Rojki Emirliğine ve yörede yaşayan halka etkilerini incelemektedir.

Anahtar Kelime: Bitlis, Rojki, Timurlular, Kara Koyunlular, Akkoyunlular.

\section{Abstract}

Bitlis was a strategic place located at an important transit-trade passage that hosted many civilizations and states throughout history. Because of this feature, many struggles were taken place for capturing the city. Especially Rojki Emirate, Timurid-Qara Qoyunid and Qara QoyunidAqqoyunid tried to dominate Bitlis in the XVth century. But the Qara Qoyunids were influence over the city, when the Timurids withdrew from the region. Şemseddin, one of the Rojki Emirs,

* Bu çalışma, Bitlis Eren Üniversitesi Bilimsel Araştırma Projeleri Koordinatörlüğü tarafindan desteklenmiştir. BEBAP 2017.16 numaralı "Bitlis Tarihi” adlı projenin sonuçlandırılması için ilgili bölümden türetilip genişletilmiştir. 
married to the daughter of Kara Yusuf in order to prevent Bitlis from the Qara Qoyunids incursions. Besides, he provided logistical support to the Qara Qoyunids for capturing the Van Lake basin. The relationship between the Bitlis Emirs and Qara Qoyunids continued on the axis of conflict during the time of the children of Qara Yusuf. The main reason of this conflicts was that the Bitlis Emirs were obeyed to the Timurids when the Timurids advanced on the Qara Qoyunids. When the Aqqoyunids became a regional power, Bitlis Emirate was stayed between the Qara Qoyunid and Aqqoyunid struggle. The Bitlis Emirs and also the Muslim and non-Muslim population of the region were influenced these struggles deeply. This study examines the effects of the struggles of the states for domination of the Bitlis and its surroundings on the Bitlis Rojki Emirate and the people living in the region.

Keywords: Bitlis, Rojki, Timurids, Qara Qoyunids, Aqqoyunids.

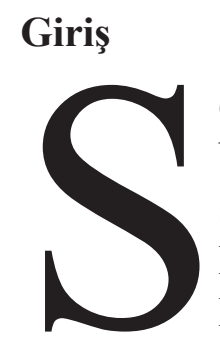

elçuklular, XI. Asrından itibaren Bitlis ve çevresinde varlık göstermesiyle birlikte bölgede hızlı siyasi dönüşümler yaşandı. Sultan Melikşah, 1085'te Mervanilere son vermesi neticesinde Selçuklu emirleri tarafından Bitlis, Erzen ve Amid'de Dilmaçoğulları, Ahlat ve Malazgirt yöresinde ise Ahlatşahlar Beyliği kuruldu. $\mathrm{Bu}$ prensliklerin yaklaşık bir asırlık ömürlerinin ardından Bitlis ve Ahlat şehirleri, çevresindeki diğer yerleşim yerleriyle birlikte sırasıyla Türkiye Selçukluları, Eyyubiler, Harzemşahlar ve tekrardan Eyyubilerin yönetimi altına girdi. Moğolların bölgeye gelmesiyle birlikte Van Gölü havzasındaki birçok yer gibi Ahlat ve Bitlis de istila edildi. Adı geçen şehirler sonra Tebriz merkezli kurulan İlhanlıların hâkimiyeti altına girdi. ${ }^{1}$

İlhanlıların kurucusu Hülagü, eskiden Ermeniyye olarak bilinen Van Gölü havzasını ve Diyar-1 Bekr bölgesini iki askeri eyalete ayırdı. Bunlar merkezi Musul olan; Musul, Mardin ve Diyarbekir'i içerisine alan Diyarbekir eyaleti, diğeri ise Bitlis ve Ahlat şehirlerinin yer aldığı Van Gölü havzasını kapsayan Ahlat merkezli eyalettir. Bu eyaletler, şehirlerin mahalli idarecilerinin yanı sıra Moğol valileri tarafindan yönetilmekteydi. ${ }^{2}$ Geniş bir coğrafyayı idaresinde tutan İlhanlılar, son hükümdarı Ebu Said Bahadır 1335'te ölünce çöküşe geçti. ${ }^{3}$ Devlet içerisindeki dâhili hadiseler ve bölgelere tayin edilmiş valiler, devletin yıkılışını hızlandırdı. İlhanlı sonrası Anadolu'nun doğu ve güney doğusunda, İran ve Irak coğrafyalarını da kapsayacak şekilde, Moğol bakiyesi prenslikler kuruldu. Bunlar, Celayirliler ve Sutaylılard.$^{4}$

1 Faruk Sümer, “Ahlat Şehri ve Ahlatşahlar”, Belleten, C. L, S. 197, Ağustos 1986, s. 453-458.

2 Faruk Sümer, Kara Koyunlular (Başlangıçtan Cihan-Şah'a Kadar), C. I, TTK Yayınları, Ankara 1967, s. 33; Hasan Taşkıran, “Genel Hatlarıyla Ortaçağ ve Sonrası Bulanık’ın Coğrafyası ve Tarihi”, Bulanık/Kop (İnsan-Coğrafya-Tarih-Kültür), (Editör; İrşad Sami Yuca), Çizgi Kitapevi, Konya 2020, s. 180. Her iki eyaletin valileri için Bkz.; Bertold Spuler, Iran Moğolları, (Çev. Cemal Köprülü), TTK Yayınları, Ankara 2011, s. 384-385.

3 Spuler, s. 144.

4 İran'ın batısı ve Irak’1n kuzeyi ile Anadolu’nun güney kısımlarında 1340-1431 yılları arasında hüküm süren bir Moğol Hanedanlığıdır. Bkz.; Mükrimin Halil Yinanç, "Celâyir”, I.A, C. III, MEB Yayınları, İstanbul 1989, s. 64-65; Muzaffer Ürekli, “Celâyirliler”, DİA, C.7, TDV. Yayınları, İstanbul 1993, s. 264265 . 
Güçlü bir beylik olarak ortaya çıkan Celayirliler, zamanla zayıflayınca Bitlis, Ahlat, Erciş ve çevresinde Kara Koyunlu Türkmenler etkinlik kazanarak Van Gölü havzasındaki şehirleri hızlıca hakimiyetleri altına aldılar. Böylece Bitlis’te hüküm süren mahalli emirler Kara Koyunlulara tabiiyete bildirdiler. Ancak Emir Timur'un bölgeye gelmesiyle birlikte ona bağlanıp Bitlis'in idaresini devam ettiler. Timur bölgeden ayrılınca Bitlis Emirleri, Kara Koyunlu ve Akkoyunlu mücadelesinin arasinda kaldı.

\section{Bitlis'te Rojki Beyliği'nin Kuruluş Süreci}

1207'de Eyyubiler, Bitlis, Ahlat ve Muş bölgesine yönelik faaliyetlerde bulundular. Önce el-Cezire hâkimi Melik Eşref ve ardından Meyyafarikin sahibi Melik Necmeddin Eyyub, Ahlat ve çevresine akınlar düzenledi. Necmeddin, Muş'u ele geçirdikten sonra Ahlat'a yöneldiyse de Erzurum Selçuklu Meliki Tuğrulşah ve Artuklu kölelerinden Balaban, onu bölgeden uzaklaştırdı. Ancak Ahlat halkı, şehri çevresiyle birlikte Eyyubilere teslim etti. ${ }^{5} 1208$ 'de Gürcü saldırılarından sonra Melik Necmeddin ve kardeşi Melik Eşref Muzaffereddin bölgede Eyyubi hâkimiyetini tesis etmeye çalıştılar. ${ }^{6}$

Mervaniler döneminden itibaren Bitlis ve çevresinin değişen demografisi adı geçen Eyyubi beyleri zamanında daha da belirginleşmeye başladı. Eyyubi ailesinin mensup olduğu Kürt Revvadilerden muhtelif kitleler Azerbaycan'dan Ahlat ve Bitlis'e gelip yerleştikleri gibi aynı dönemde Eyyubiler tarafından Hakkari bölgesinden Kürt aşiretleri de yöreye iskan ettirildi. Bu iskânın temel amacı Türkiye Selçukluları ve mahalli Beyliklere karşı set oluşturmaktı. ${ }^{7}$ Böylece Bitlis ve çevresine göç eden 24 Kürt aşireti bir araya gelip Rojki/Rozki (روزكى-روزكى) aşiret konfederasyonunu teşkil ederek Bitlis Beyliğini kurdular. ${ }^{8}$ Bu beylik sonraları Şerefhanlar Emirliği tesmiyesiyle anild1.

1229'da Celaleddin Harzemşah'1n Ahlat'1 zapt etmesiyle onu takip eden Moğollar, bölgeye gelerek istilada bulundular. ${ }^{9} \mathrm{Bu}$ istila, ilim ve kültür merkezi olan Ahlat ve Bitlis için karanlık bir döneme yol açtı. İstila sonrasında İlhanlıların kurucusu Hülagü, eskiden Ermeniyye olarak bilinen Van Gölü havzasını ve Diyar-1 Bekr bölgesini iki askeri eyalete ayırdı. Bunlar merkezi Musul olan; Musul, Mardin ve Diyarbekir'i içerisine alan Diyarbekir eyaleti, diğeri ise Bitlis ve Ahlat şehirlerinin yer aldığı Van Gölü havzasını kapsayan Ahlat merkezli eyaletti. Bu eyaletler, şehirlerin

5 İbnü'l-Esir, El-Kâmil Fi't-Tarih, C.XII, (Çev. Ahmet Ağırakça-Abdülkerim Özaydın), Bahar Yayınları, İstanbul 1987, s. 228-229; Osman Turan, Doğu Anadolu Türk Devletleri Tarihi, Ötüken Neşriyat, İstanbul 2009, s. 124-125.

6 Gregory Abû'l-Farac, Abû'l-Farac Tarihi, C. II, (Çev. Ömer Rıza Doğrul), TTK Yayınları, Ankara 1987, s. 491.

7 Mükrimin Halil Yinanç, "Bitlis”, İ.A. C. II, MEB Yayınları, İstanbul 1979, s. 663; Turan, s.134; Derya Coşkun, “Tebriz'de Kurulan Feodal Bir Devlet: Revvâdiler (948/1071)", Tarihin Peşinde Uluslararası Tarih ve Sosyal Araştırmalar Dergisi, S. 23, 2020, s. 5-6; Revvâdî ve Hezbânîlerin Van Gölü Havzasına gelişleri için Bkz.; Nevzat Keleş, "Van Gölü Havzası'nda Revvâdî ve Hezbânî Hâkimiyeti”, Tarihi ve Kültürel Yönleriyle Bitlis, C. I, (Editör: Mehmet İnbaşı, Mehmet Demirtaş), Bitlis Eren Üniversitesi Yayınları, Ankara 2019, s. 103-115.

8 Rivayete göre Rojki aşireti; 24 Kürt Aşiretin bir günde Hovit nahiyesi dolaylarında Tab denilen yerde toplanıp ittifak kurmalarından oluşmuştur. Bkz.; Şerefhan, Şeref-name, C. I, (Editor by Vladimir Veliominof-Zernof), St. Petersbourg 1860, s. 358.

9 Hamdullah Müstevfî-yi Kazvinî, Târih-i Güzide, (Çev. Mürsel Öztürk), TTK Yayınları, Ankara 2018, s. 400; Cüveynî, Tarih-i Cihan Güşa, (Çev. Mürsel Öztürk), TTK Yayınları, Ankara 2013, s. 372. 
mahalli idarecileri yanı sıra Moğol valileri tarafından yönetilmekteydi. ${ }^{10}$ XIV. Asırdan itibaren İlhanlıların inkırazına müteakip Celayirli, Sutaylı ve Hülagü soyunun takipçileri arasında vuku bulan mücadeleler döneminde Yakındoğu coğrafyasında büyük istikrarsızlık meydana geldi. Bitlis Kürt Rojki Beyliği hem Moğol valileri döneminde hem de İlhanlı sonrası fetret döneminde varlığını sürdürdü. XV. Asırda Bitlis Rojki Beyleri, Moğollardan sonra Van Gölü havzasına tahakküm eden güçlerin tabiiyetinde varlık göstermekteydi. Bunu dönemin kaynaklarındaki dağınık ve eksik bilgilerle müşahede etmek mümkündür. Çünkü kaynaklarda, sadece metbuluk, bağl1lık takdimleri veya doğrudan Bitlis'i ilgilendiren hususlar sırasında Bitlis Beylerinden bahsedilmektedir. Dönemin kaynaklarında Bitlis hâkimlerinden çok az bahsedilmesi Bitlis Rojki Beyliği tarihinin birçok noktasının karanlıkta kalmasına neden olmaktadır.

\section{Rojki Beyliği, Timurlu ve Kara Koyunluların Hâkimiyetinde Bitlis ve Çevresi}

İlhanlıların yıkılması ve Moğol Beyliklerinin aralarındaki mücadeleyi fırsat bilen Kara Koyunlu Türkmenler, Erciş’te beyliklerini tesis etmeye başladılar. Sonraları Erciş ve Musul hattındaki coğrafyaya yayıldılar. Kara Koyunlular, Moğol valileri gibi kışları Musul, yazları Muş ve Ahlat'ta geçirmekteydi. Bu beyliğin bilinen ilk reisi Bayram Hoca'dır. Kara Koyunlu reisi 1365 'ten itibaren Erciş merkez olmak üzere Erzurum'dan Musul'a kadar olan bölgeye hükmetti. Bölgedeki mahalli beyleri kendisine tabii kılan Bayram Hoca, Mardin'i kuşattı. Ancak Mardin Artuklu hükümdarı el-Melik Mansur Ahmed, Celayirli hükümdarı Sultan Üveys'ten yardım talep etti. Sultan Üveys, 1366 'da önce Birdi Bey'in elinde bulunan Musul üzerine yürüyerek buray1 alıp adı geçen Kara Koyunlu beyini esir etti. Bu sırada Bayram Hoca, Muş ovasında yaylada bulunmaklaydı. Sultan Üveys, Bayram Hoca'nın üzerine yürüyerek Musul'dan Mardin'e buradan da Beşiri'ye gelip Muş yönünde ilerledi. Murat Suyunu geçen Sultan Üveys, Muş ovasında Bayram Hoca ile karşı karşıya geldi. Kara Koyunlu Bey'i karşılaşma sırasında bozguna uğrayarak kaçtı. Celayirlilere vergi vermeyi kabul eden Bayram Hoca, Karakilise yoluyla Tebriz'e geçen Sultan Üveys'in gidişini firsat bilip 1369'da Musul'u kuşatarak burayı tekrardan ald. Kara Koyunlu Bey'i Musul'u kuşattı̆̆g sırada Bitlis'in Kürt Beyleri ve yöredeki diğer emirler ona destek sağladılar. Bu durum Bitlis Rojeki Beylerinin 1369'dan önce (muhtemelen 1360'ta) Kara Koyunlulara tabii oldukları ve bu yüzden onlara yardım ettiklerini ortaya koymaktadır. Bu destek 1371'deki Musul kuşatması sırasında da verildi. ${ }^{11}$

1374 'te Celayir hükümdarı Sultan Üveys vefat edince ülkesi Muzafferilerin istilasına uğradı. Bu durumdan yararlanan Bayram Hoca, başta Van Gölü havzasında Aladağ ve Akkilise olmak üzere Hoy ve Nahcivan'ı aldı. Musul'da hâkimiyetini pekiştirerek Sincar'ı da ele geçirdi. Ayrıca daha önce Celayirlilere ödediği vergiyi de kesti. Yaşananlar karşısında Celeyirlilerin yeni hükümdarı Sultan Hüseyin, 1377'de Bayram Hocanın üzerine tedip seferine çıktı. Sultan Hüseyin, Van Gölü çevresinde meşhur Bend-i Mahi (بند ماهى)'yi bir saate ele geçirdi. Oradan Aladağ'a geldiğinde Bayram Hoca Erzurum taraflarına kaçtı. Sultan Hüseyin, Bayram Hoca'nın yeğeni Kara Mehmed'in elinde bulunan Erciş'i kuşattı. Kara Mehmed, tabiiyet bildirmesi ve vergi vermeyi kabul etmesi neticesinde Erciş onun idaresinde bırakıldı. ${ }^{12}$ Celayirlilerin baskılarına rağmen Bayram Hoca

10 Sümer, Kara Koyunlular (Başlangıçtan Cihan-Şah'a Kadar), s. 33; Spuler, s. 384-385.

11 Thomas A. Sinclair, "Karakoyunlular Döneminde Ermeniler ve Bitlis'in Kürt Emirleri”, Tarihi Kentler ve Ermeniler/Bitlis ve Muş, Ed. Richard G. Hovannisian, (Çev. Zülal Kılıç), Aras Yayınları, İstanbul 2016, s. 162.

12 Hâfız-1 Ebrû, Zübdetü’t-Tevârîh, C. 1, (Neşr. Seyyid Kemal Hâc Seyyid Cevadi), Vizâret-i Ferheng ve 
döneminde Kara Koyunların sınırları, Bitlis ve Ahlat'taki mahalli idarenin bağlılı̆̆ıyla birlikte Erciş'ten Musul'a kadar olan sahayı kapsamaktaydı. ${ }^{13}$

1380 'de Bayram Hoca vefat edince onun yerine yeğeni Erciş müdafisi Kara Mehmed, Kara Koyunluların başına geçti. ${ }^{14}$ Kara Mehmed, bir taraftan Celayirlilerin iç işlerine müdahil olup Şeyh Ali'ye karşı Ahmed'i destekleyip tahta çıkartırken diğer taraftan Artuklularla sihriyet bağı kurarak güneydeki topraklarını güvence altına almaya çalıştı. Öte taraftan ezeli ve ebedi rakipleri Akkoyunlu tehlikesini bertaraf için Erzincan Emiri Mutahharten'e yardım etmekteydi. ${ }^{15}$

Kara Koyunluların Doğu Anadolu'nun tamamına yakın coğrafyada hâkimiyet kurması Batı İran'1 zapt eden Emir Timur'u harekete geçirdi. ${ }^{16} 1386$ yılının kışını Karabağ' da geçiren Timur, 1387'nin baharında harekete geçerek Anadolu'nun doğusuna girdi. ${ }^{17}$ Bölgeyi istila için firsat kollayan Timur, ilk önce Bayezid/Doğubayazıd'a gelip burayı yağmaladı. Kendisine bağlılık bildirmeyen Kara Mehmed'i hac kafilelerine ve ticaret kervanlarına saldırmakla suçlayarak onun üzerine yürüdü. ${ }^{18}$ Kara Koyunluların elindeki Avnik kalesi önüne gelen Timur, buranın alınmasının uzun süreceğini düşündüğünden Erzurum tarafına yöneldi. Erzurum'u ele geçiren Timur, Çapakçur (Bingöl) tarafında bulunan Kara Mehmed'in üzerine birliklerini gönderdi. Ancak Kara Mehmed, bu birliklere karşı mukavemet göstererek onları geri püskürttü. ${ }^{19}$ Mağlubiyet karşısında hiddetlenen Timur, ölen askerlerinin intikamı için Kara Mehmed'in peşine yeni birlikler gönderdi. Kendisi ise Muş ovasına inerek buradaki Türkmen oymalarını yağmaladı. Muş ovasından ayrılan Timur, Malazgirt ve Erciş'e gitti. Önce Ahlat'1 sonra Adilcevaz'1 alarak Aladağ'a yönelip burada otağını kurdu. Timur, Aladağ'da bir müddet kaldıktan sonra ağırlıklarıyla birlikte Van Gölü sahiline inerek Van şehrini aldı. ${ }^{20}$ Buranın idaresini kendisine tabii kıldığı Hakkâri Emiri İzzeddin Şir'e bıraktı. ${ }^{21}$ Hatta sonraları İzzeddin Şir, Timurlu kuvvetlerle birlikte Kara Mehmed'in üzerine yürüdüyse de bir başarı elde edemedi. ${ }^{22}$ Timur, Kara Mehmed'i ele geçiremeyeceğini anlayınca İran’a döndü. ${ }^{23}$

İrşad-i İslâmî, Tahran 1385, s. 526-527.

13 Kadı Ahmed Gaffarî Kazvinî, Tarih-i Cihan Âra, (Nşr. Hasan Neraki), İntişârt-1 Kitabfuruşi Hafız, Tahran 1343, s. 248.

14 Yahyâ Kazvînî, Lübbü t-Tevârîh, (Haz. Seyyid Celaleddin Tehrani), Tahran 1314, s. 211.

15 Aziz b. Erdeşir-i Esterâbadî, Bezm u Rezm, (Çev. Mürsel Öztürk), Kültür Bakanlığı Yayınları, Ankara 1990, s. 343.

16 İsmail Aka, Timur ve Devleti, TTK Yayınları, Ankara 2014, s. 21.

17 Makrîzî, es-Sulûk li-Ma'rifeti Duvel el-Mulûk, C. V, (Thk. Muhammed Abdulkadir 'Atâ), Dâru'lKutubi'l-'İlmiyye, Beyrut 1997, s. 190.

18 Hâfız-1 Ebrû, C. 2, s. 664.

19 Nizamüddin Şâmî, Zafernâme, (Çev. Necati Lugal), TTK Yayınları, Ankara 1987, s. 124; Hâfız-1 Ebrû, C. 2, s. 664.

20 Hâfız-1 Ebrû, C. 2, s. 665; Hayrunnisa Alan, Bozkırdan Cennet Bahçesine Timurlular 1360-1506, Ötüken Neşriyat, İstanbul 2015, s. 40.

21 Şerefüddin Ali Yezdî, Zafernâme, (Çev. Ahsen Batur), Selenge Yayınları, İstanbul 2013, s. 159; Nizamüddin Şâmî, s. 125.

22 Dündar Alikılıç, Abbasî Devleti’nden Hakkâri Beyliği'ne İrisân Beyleri, Tarih Düşünce Kitapları, İstanbul 2006, s. 46-47.

23 Nizamüddin Şâmî, s. 125; Sümer, Kara Koyunlular (Başlangıçtan Cihan-Şah'a Kadar), s. 49-51; Aka, Timur ve Devleti, s. 21; Hasan Geyikoğlu, "Kara-Koyunlular'ın Van-Gölü Çevresindeki Faaliyetleri ve Günümüze Ulaşabilen Kültürel Mirasları", Türkiyat Araşstırmaları Enstitüsü Dergisi, S. 38, Erzurum 2008, s. 212. 
Timur, İran'dan Maveraünnehir'e yöneldiğinde Kara Mehmed, tekrardan Van Gölü havzasına döndü. ${ }^{24}$ Buradan İran'a gidip Tebriz'e bir fatih gibi girdi. Ancak Kara Mehmed'in bu başarısı kısa süre sonra amcasının oğlu Pir Kara Hasan'ın isyan ile son buldu. 1389'da isyanı bastırmak isteyen Kara Mehmed, Pir Hasan'la savaşı sırasında öldü. ${ }^{25}$ Pir Hasan galibiyetinin ardından Kara Koyunluların başına geçmek istediyse de Türkmenler buna rıza göstermeyerek Kara Mehmed'in oğlu Misır Hoca'nın etrafında toplandılar. Ancak Kara Mehmed'in diğer oğlu Kar Yusuf (13891420) Kara Koyunluların başına geçti. Kara Yusuf, Türkmenlerin liderliğini üstlenince Van Gölü havzasındaki şehirlerde hâkimiyetini tesis etti. Celayirlilerin iç mücadelesini firsat bilip 1391'de Tebriz'e gelip hâkimiyetini pekiştirdi. ${ }^{26}$ Çok geçmeden Timur'un Bağdat yönüne doğru harekete geçtiğini anlayan Kara Yusuf, Tebriz'i terk ederek Erciş üzerinden Muş ovasına geldi. 1393'te Timur, Bağdat'1 alıp Celayirli Ahmed'i Halep tarafına kaçmaya mecbur ettikten sonra kuzeye yöneldi. ${ }^{27}$ Musul ve çevresindeyken bölgedeki emirlerin yanı sıra Kara Koyunlu ve Akkoyunlu Beylerine itaat için haber yolladı. Buna mukabil Musul valisi Yar Ali ve Erbil Emiri Şeyh Ali değerli armağanlarla onu ziyaret edip bağlllık bildirdiler. Böylece bu beyler mevkilerini korudular. ${ }^{28}$ Musul'dan Mardin'e yönelen Timur, bölgedeki şehirler; Kerkük, Erbil, Musul, Mardin ve Diyarbekir'i aldı. Re'sul-Ayn'a vardığında, bölgedeki Kara Koyunluların üzerine ordusunun sağ kol birliklerini gönderdi. ${ }^{29}$

Emir Timur'un tabiiyet haberine Anadolu'da Dulkadirli Suli Bey, Karamanoğlu Aleaddin Ali Bey ve Erzincan Emiri Mutahharten olumlu cevap verip itaat bildirirken Kara Yusuf, bağlllik bildirmedi. ${ }^{30}$ Bunun üzerine 1394'te Timur, ağırlıklarıyla birlikte Kara Yusuf'un bulunduğu Muş ovasına geldi. Timur'un geldiğini öğrenen Kara Yusuf mahiyetindeki Türkmenlerle birlikte oradan ayrıldı. Emir Timur, Kara Yusuf'u yakalatmak için komutanlarından Burhanoğlan'1 peşinden gönderdiyse de bir başarı elde edilemedi. Burhanoğlan'ın başarısız seferi sonrasında Timur, Muş ovasında çok kalmayarak Van Gölü'nün kuzeyinde bulunan Aladağ'a geldi. ${ }^{31}$ Buradayken önceleri belli dönemlerde Kara Koyunlulara bağlı bulunan Bitlis Emiri Hacı II. Şeref, Timur'un huzuruna gelip itaat bildirip ona kıymetli atlar hediye etti. Yaklaşık yüz at hediye getiren Hacı Şeref, ovada yapılan yarışta tüm atları geçen kendi atını ise bizzat Timur'a verdi. ${ }^{32}$ Nizamüddin Şâmî, Bitlis Emiri Hacı II. Şeref için; "bütün Kürdistan vilayetinde bunun gibi doğru sözlü, ahlak sahibi bir adam yoktur" 33 ifadelerini kullanmaktadır. Bitlis Emirinin tabiiyetine karşılık Timur, ona iltifatlarda bulunup bir zerduz hilat ve altın süslemeli kemer hediye ederek Bitlis ve çevresini onun idaresinde

24 Makrîzîye göre Kara Mehmed, Timur’a yenilince Malatya önlerine kaçışmıştı. Bkz.; Makrîzî, C. V, s. 199.

25 Ebû Bekr-i Tihrani, Kitab-ı Diyarbekriyye, (Çev. Mürsel Öztürk), TTK Yayınları, Ankara 2014, s. 36.

26 Hâfız-1 Ebrû, C. 2, s. 750-751.

27 Şerefüddin Ali Yezdî, s. 219-221; Makrîzî, C. V, s. 338.

28 Nizamüddin Şâmî, s. 177-178.

29 Aziz b. Erdeşir-i Esterâbadî, s. 414; Aka, Timur ve Devleti, s. 28.

30 Aka, Timur ve Devleti, s. 28.

31 Sümer, Kara Koyunlular (Başlangıçtan Cihan-Şah'a Kadar), s. 57.

32 Şerefüddin Ali Yezdî, s. 240.

33 Nizamüddin Şâmî, s. 185; Kemaleddin Abdurrezzak-i Semerkandî, Matla'-ı Sa'deyn ve Mecma'-ı Bahreyn, C. I/II, (Neşr. Abdul Hüseyin Nevâi), Pejuhaşkah-1 Ulum-i İnsanı ve Muta’alat-1 Ferhengi, Tahran 1383, s. 698. 
bırakt1. ${ }^{34}$ Ayrıca Adilcevaz Emri Hakan (خقن) da Timur'a itaat bildirdi. Timur'un iltifatına mazhar olan bu Emire de Ahlat suyurgal olarak verildi. ${ }^{35}$

Timur, Aladağ'da bağlılık kabullerini aldıktan birkaç gün sonra Kara Yusuf'un kardeşi Mısır Hoca'nın elinde bulunan Erzurum yakınlarındaki Avnik kalesini almak için harekete geçti. Ağırlıklarıyla kalenin önüne gelen Timur, burayı yaklaşık 43 gün kuşattıktan sonra 31 Temmuz 1394'te aldı. Kalenin müdafisi Mısır Hoca'yı esir alarak Mardin Meliki İsa ile birlikte Sultaniye'ye gönderdi. Kısa süre sonra onu Sultaniye'den Semerkand'a gönderip orada öldürdü. Timur, Avnik'in idaresini Atlamış'a verdikten sonra Gürcistan'a yöneldi. ${ }^{36}$ Timur'un bölgeden ayrılmasıyla birlikte Kara Yusuf tekrardan Van gölü havzasına dönerek Erciş’i aldı. Erciş’in düştüğünü öğrene Timur'a bağlı Van ve Hakkâri hâkimi İzzeddin Şir, Timurlu destek kuvvetleriyle Kara Yusuf'un üzerine yürüdüyse de başarılı olmadı. Bu sırada İzzeddin Şir'e destek için gelen Avnik Kale hâkimi Atlamış, 1395 'te Erciş'te Kara Koyunlu Türkmenler tarafından esir alındı. Kara Yusuf, Emir Atlamış’1 sonraları Mısır'a Memlüklü Sultanı Berkuk'a gönderdi. ${ }^{37}$

Kara Yusuf, Timur'un Toktamış Han Seferine çıktığı sırada Van Gölü havzasında kaybettiği toprakları geri almaya çalıştı. Ancak Timur, başarılı Deşt-i Kıpçak ve Hindistan seferleri neticesinden Semerkand'a oradan 1399/1400'de Azerbaycan'a gelip Karabağ'da kışladı. Gürcistan ve Irak-1 Arap'ta faaliyetlerde bulunduktan sonra Bingöl'e gelince Anadolu ve Suriye istilasına karar verdi. Timur'un Anadolu'ya girdiğini anlayan Kara Yusuf, Van Gölünden ayrılarak Musul'a geldi. Bu sırada Celayirli Ahmed'de onun yanına geldi. Timur'un Bingöl'den Sivas'a doğru ilerlediğini öğrenen Kara Yusuf, Celayirli Ahmed ile birlikte Mısır'a gitmek istediyse de Halep naibi Timurtaş buna izin vermedi. ${ }^{38}$ Timur'un Sivas'1 alarak güneye inmeye başladığında Kara Yusuf ve Celayirli Ahmed, Osmanlı Sultanı Bayezid'e sığındı. ${ }^{39}$ Ancak Ankara Savaşının (1402) biraz öncesinde Kara Yusuf ve Celayirli Ahmed, ağırlıklarıyla Bağdat'a gelmişlerdi. Kara Yusuf, Celayirli Ahmed'in oğlu Hille hâkimi Tahir ile mücadelesinde ona destek oldu. Mücadele sirasında Tahir suda boğulup ölünce Celayirli Ahmed Bağdat'a dönerken Kara Yusuf, Hille'de kaldı. Kısa süre sonra Kara Yusuf ile Ahmed'in arası açıld1. Kısa süre sonra Kara Yusuf, Hille'den Bağdat'a yürüdü. Ahmed'i kaçmaya mecbur ederek Bağdat'1 aldı (1403). Irak’taki vaziyeti öğrenen Timur, torunları Ebu Bekir Mirza ile Emirzade Rüstem'i Kara Yusuf'un üzerine gönderdi. Timurlu Mirzalar ve askerleriyle mücadele etmeye çalışan Kara Yusuf mağlup oldu. Hatta Hanımı esir düştüğü gibi kardeşi Yar Ali savaş sırasında öldü. Kendisi ise çöle kaçarak Şam’a geldi. ${ }^{40}$

34 Şerefüddin Ali Yezdî, s. 240; Şeref Han, Hacı II. Şeref'in Timur'u ziyaretinde Bitlis, Ahlat, Muş ve vilayetlerinde bulunan kaleleri ona teslim ettiğini, Timur'un mevcut vilayet Bitlis'in yanı sıra Pasin, Avnik ve Malazgirt gibi yerlerin idaresini de Hacı Şeref'e verdiğini belirtmektedir. Bkz.; Şerefhan, C. I, s. 372-373.

35 Nizamüddin Şâmî, s. 186.

36 İbn Arabşah, Acâibu'l-Makdûr, (Çev. D. Ahsen Batur), Selenge Yayınları, İstanbul 2012, s. 123-124; Enver Konukçu, “Kara Koyunlular’ın Avnik Kalesi”, Prof. Dr. İsmail Aka Armağanı, İzmir 1999, s. 3840.

37 Sümer, Kara Koyunlular (Başlangıçtan Cihan-Şah'a Kadar), s. 59; Şehabeddin Tekindă̆, Berkuk Devrinde Memluk Sultanlı̆ğ, İstanbul Üniversitesi Edebiyat Fakültesi Yayınları, İstanbul 1961, s. 93.

38 Hâfız-1 Ebrû, C. 2, s. 892.

39 Nizamüddin Şâmî, s. 293; Handmir, Tarih-i Habibü’s-Siyer, C. 3, Kitabhane-i Hayyam, Tahran 1333, s. 485-486; Aka, Timur ve Devleti, s. 28.

40 Şerefüddin Ali Yezdî, s. 414-415; Handmir, C. 3, s. 516-517; Ebû Bekr-i Tihrani, s. 48. 
Kara Yusuf, Şam'a geldiğinde buradaki Memlüklü naibi Şeyh Mahmudî tarafindan iyi karşılandı. Sonrasında Celayirli Ahmed de Şam'a gelerek eski dostuyla barıştı. Şeyh Mahmudi, Sultan Ferec'in emriyle iki yol arkadaşını tutuklamak zorunda kaldıysa da Mısır Sultanının onları öldürme emrini yerine getirmedi. ${ }^{41}$ Yaklaşık olarak bir yıl esarette tutulan iki yol arkadaşı kendi aralarında anlaştı. Irak-1 Arap'ı Ahmed, Azerbaycan'ı ise Kara Yusuf aldı. Mısır Sultanı olmak isteyen Şam naibi isyan hazırlıkları sırasında kendilerine destek olmaları için Kara Yusuf ve Celayirli Ahmed'i serbest bıraktı (1405). Bölgede beylerinin kurtulmasını bekleyen Kara Koyunlu Türkmenler, Kara Yusuf serbest kalınca ona katıldılar. Kara Yusuf, yanındaki birliklerle ata toprağ 1 Van gölü çevresine gelmek için harekete geçti. Şam'dan Mardin önlerine gelene kadar yaklaşık 180 defa (muhtemelen abartılı bir rakam) Memlüklü kale ve sınır muhafızlarıyla çarpıştı. ${ }^{42}$ Kışı Musul'da geçiren Kara Yusuf, bahar olunca Nusaybin taraflarına geldi. Buradayken Mardin Meliki, Cezire hâkimi, Süleymani ve Zerki/Zırki Kürt aşiretleri kendisine katıldı. Bu katılımdan sonra Mardin ve Hasankeyf arasındaki Takı denilen mevkide Akkoyunlu Kara Yülük Osman Beyle savaştı. Savaşın neticesiz kalmasından dolayı iki taraf arasında barış yapıldı. ${ }^{43}$

Kara Yusuf, Akkoyunlularla yapmış olduğu barıştan sonra ata yurdu Erciş ve çevresine doğru yol aldı. Bitlis'e vardığında buranın hâkimi Hacı II. Şeref' in oğlu Emir II. Şemseddin, onu karşıllayıp değerli hediyeler sunup Kara Koyunlu askerlerinin ihtiyaçlarını giderdi. Kara Yusuf ise ona kızını verip desteğini aldıktan sonra Timur'a bağlı bulunan ve kendisine düşmanlık yapan Van hâkimi İzzeddin Şir'in üzerine yürüdü. Onu mağlup ederek kendisine bağladı. Bitlis Emiri Şemseddin, Kara Koyunlu beyine sadakatle bağlı kalırken Van Emiri İzzeddin, ona şeklen tabiiyet gösterip bu beyden kurtulmanın yollarını aradı. Zira Kara Yusuf'un avdetini duyan bölgedeki Türkmen ve Kürt Beyleri gelip ona bağl11ık bildirmekteydiler. Kara Yusuf'un giderek güçlenmesinden endişe eden İzzeddin Şir, çok geçmeden Azerbaycan ve Irak-1 Acem'in hâkimi Timur'un torunu Miranşah'ın oğlu Mirza Ebu Bekir'e gizlice haberler yollayarak Kara Koyunlulara karşı kışkırttı. Bu sırada Kara Yusuf, Avnik üzerine yürüdü. Burayı Doladay'dan aldıktan sonra Van Gölü havzasına yeniden hâkim oldu. ${ }^{44}$ Kara Koyunlu Bey’i Azerbaycan'a hâkim olabilmek için Mirza Ebu Bekir ile savaşması gerekmekteydi. Çok geçmeden bu savaş 14 Ekim 1406'ta Aras Çayı mevkiinde meydana geldi. Kara Yusuf, Mirza Ebu Bekir'i ağır bir yenilgiye uğratarak Nahçivan'dan Merend'e oradan da Tebriz önlerine kadar geldi. ${ }^{45}$

Kara Yusuf, Azerbaycan'da otoritesini sağladıktan sonra tekrardan Anadolu'ya dönmek durumunda kaldı. Akkoyunlu Kara Yülük Osman Bey, Mardin'e saldırınca Artuklu hükümdarı Melik Salih, Kara Yusuf'a yardım için haber gönderdi. ${ }^{46}$ Muş ovasında Melik Salih'in haberi kendisine ulaşan Kara Yusuf, yanına damadı Bitlis Hâkimi Şemseddin, Emir Sehend (سهند) ve

\footnotetext{
41 Handmir, C. 3, s. 530.

42 Hasan-1 Rumlu, Ahsenü’t-Tevarih, (Çev. Mürsel Öztürk), TTK Yayınları, Ankara 2006, s. 54; Şerefhan, C. I, s. 376; Kadı Ahmed Gaffarî Kazvinî, s. 248.

43 Ebû Bekr-i Tihrani, s. 49.

44 Hasan-1 Rumlu, s. 54; İsmail Aka, Mirza Şahruh ve Zamanı (1405-1447), TTK Yayınevi, Ankara 1994, s. 51; Sümer, Kara Koyunlular (Başlangıçtan Cihan-Şah'a Kadar), s. 69. Şeref Han, Bitlis Emiri Şemseddin'in desteklerinden dolayı Kara Yusuf'un ona kızını verip Pasin bölgesi ve Avnik kalesini de hediye ettiğini yazar. Bkz.; Şerefhan, C. I, s. 376.

45 Hasan-1 Rumlu, s. 55-58; İsmail Aka, İran'da Türkmen Hâkimiyeti (Kara Koyunlular Devri), TTK Yayınları, Ankara 2001, s. 5.

46 Ebû Bekr-i Tihrani, s. 55.
} 
bölgedeki diğer bazı emirlerle birlikte Diyarbekir önlerine gelip Akkoyunlu Kara Yülük Osman Bey'i mağlup ettiler (1409). ${ }^{47}$ Daha sonra Mardin'e gelen Kara Yusuf, kızlarından birini Melik Salih ile evlendirerek onu Musul idaresine getirdi. Mardin'in idaresini de adamlarından Ali'ye verdi. Çok geçmeden Melik Salih'in ölümü üzerine Artukluların son kolu da ortadan kalktı. ${ }^{48}$

1410'da Kara Yusuf, Aladağ'a geldiğinde birçok kimseler onun yanına gelip Erzincan hâkimi Mutahharten'in torunu Şeyh Hasan'dan şikâyetçi oldu. Kara Yusuf, Şeyh Hasan'1 cezalandırmak için Erzincan'a yürüdü. Şehri kuşattığı sırda eski gurbet ve yol arkadaşı Celayirli Ahmed, Hemedan çevresinin kendisine bırakılmadığı bahanesiyle Bağdat'tan Azerbaycan'a geldi. Tebriz'de bulunan Kara Yusuf'un büyük oğlu Şah Mehmed, Hoy taraflarına çekilmek zorunda kaldı. ${ }^{49}$ Bunun üzerine Celayirli Ahmed, Tebriz'i alarak bütün Azerbaycan'ı hâkimiyeti altına aldı. Celayirli Ahmed'in Tebriz'i aldığını öğrenen Kara Yusuf, Erzincan'1 alıp Azerbaycan'a yöneldi. Tebriz önlerine geldiğinde eski dostu Celayirli Ahmed, şehrin yakınlarındaki Şenb-i Ğazan (شنب غازان)'a gelip karargâh kurdu. 30 Ağustos 1410'da Esed köyü mevkiinde eski müttefik birlikleri karş1 karş1ya geldi. Burada dikkati çeken husus Kara Yusuf'un ordusunda birçok Türkmen ve Kürt Beyinin yanı sıra damadı Bitlis hâkimi Emir Şemseddin'de bulunmaktayd1. ${ }^{50}$ Emir Şemseddin, Kara Koyunlu ordusunun sol kolunda yer almaktaydı. İki tarafın karşılaşması neticesinde Celayirli Ahmed mağlup olup kaçtı. Gizlendiği bahçede yakalanarak Kara Yusuf’un huzuruna getirildi. Nihayetinde Celayirli beylerinin 1srarıyla öldürüldü. Ayrıca Şah Veled ve Celayirli Ahmed'in oğlu Adilcevaz kalesinde hapis bulunan Alauddevle de öldürüldü. ${ }^{51}$

Bitlis Emiri Şemseddin ile Kara Yusuf arasında çok yakın bir ilişki vardı. Kara Yusuf, hem kendi kızını onunla evlendirerek kurmuş olduğu sıhriyet bağı hem de kendisine sağladığ desteklerden dolayı ona "oğlum” diye hitap etmekteydi. Emir Şemseddin, Kara Yusuf'un ölümüne kadar ona sadık kalarak askeri ve lojistik manada destek sağladı. Bu desteklerin neticesinde Kara Yusuf, başta Bitlis olmak üzere Ahlat, Muş, Hınıs ve buraya bağlı kalelerin idaresini eskiden olduğu gibi yeniden damadı Emir II. Şemseddin'e ait olduğuna dair 27 Nisan 1417 tarihli bir ferman verdi. Böylece Emir Şemseddin'in idare ve mülkiyet sahası pekişmiş oldu. ${ }^{52}$

Kara Yusuf, Azerbaycan'da Timurluları, Anadolu'da ise Akkoyunlu Kara Yülük Osman Bey'i tehdit etmekteydi. Bu durumdan rahatsız olan Kara Yülük Osman, tabiiyetine girdiği Timurlu hükümdarı Mirza Şahruh’a başvurarak Kara Koyunluların üzerine yürümesi için ikna etmeye çalışmaktayd. Nitekim Kara Yusuf, Kazvin ve Sultaniye gibi Azerbaycan'ın önemli ticaret şehirlerini ele geçirince Şahruh, 25 Ağustos 1420'de Herat'tan Azerbaycan'a doğru sefere çıktı. Şahruh ağırlıklarıyla Akhoca'ya geldiği zaman kendisine Kara Yusuf (13 Kasım)'un öldüğü

47 Hâfız-1 Ebrû, C. 3, s. 357; Kemaleddin Abdurrezzak-i Semerkandî, C. II/I, s. 172.

48 Ebû Bekr-i Tihrani, s. 55; Sümer, Kara Koyunlular (Başlangıçtan Cihan-Şah'a Kadar), s. 80; İlhan Erdem, “Akkoyunlu Devleti’nin Kurucusu Kara Yülük Osman Bey’in Hayatı ve Faaliyetleri”, Dil ve Tarih Coğrafya Fakültesi Dergisi, C. XXXIV, S. 1-2, Ankara 1990, s. 102.

49 Hasan-1 Rumlu, s. 77-78, 80-81.

50 Tacü's-Selmani, Tarihnâme, (Çev. İsmail Aka), TTK Yayınları, Ankara 1999, s. 93; Hâfız-1 Ebrû, Kara Yusuf'un ordusunda bulunan beylerin isimlerini tek tek yazmaktadır. Bkz.; Hâfız-1 Ebrû, C. 3, s. 400401.

51 Hâfı-1 Ebrû, C. 3, s. 401-402; Hasan-1 Rumlu, s. 85-86; Sümer, Kara Koyunlular (Başlangıçtan CihanŞah'a Kadar), s. 83-86; Aka, Iran'da Türkmen Hâkimiyeti (Kara Koyunlular Devri), s. 9-10.

52 İlgili fermanın detayları için Bkz.; Şerefhan, C. I, s. 377-378. 
haberi ulaştı (17 Kasım 1420). Kara Yusuf'un cesedi Erciş'e ata ve dedesinin mezarının yanına defnedildi..$^{53}$

Bitlis hâkimi Emir II. Şemseddin, kayınpederi Kara Yusuf'un ölümünden sonra bölgeye gelip Karabağ'da kışlayan Mirza Şahruh'a adamlarını göndererek itaatlerini bildirdi (24 Aralık 1420). Bu sırada Van hâkimi İzzeddin Şir, bizzat Şahruh'un huzuruna geldi. ${ }^{54}$ Bölgedeki bey ve emirlerin birçokları Şahruh'a bizzat veya adamlarını göndererek bağlılık bildirmelerinin yanı sıra Adilcevaz ve Beyazid idaresini elinde tutan Kara Yusuf'un oğlu İsfend Bey de tabiiyet için adamlarını gönderdi. Kara Yusuf' un diğer oğlu İskender Bey ise Mardin, Musul ve Kerkük hattında Akkoyunlu Kara Yülük Osman ile mücadele ederek önemli kazanımlar elde etmekteydi. Öyleki İskender Bey, Sincar'da Kara Yülük Osman'1 mağlup etti. ${ }^{55}$

Şahruh, İsfend Bey'in bağl1lı̆̆ına güvenmeyerek onun üzerine harekete geçti. Aras Irmağı yakınındayken Emir II. Şemseddin, Kadı Muhammed isimli elçisini birçok kıymetli hediyeyle birlikte Şahruh'un huzuruna gönderdi. Timurlu karargâhına ulaşan Kadı Muhammed iyi karşılandı ve burada kurulan meclise de misafir edildi. ${ }^{56}$ Beyazid kalesini alan Şahruh, buradan Aladağ yaylası üzerinden Erciş'e indi. ${ }^{57} \mathrm{Bu}$ sırda İsfend Bey de Muş yaylasında bulunmaktaydı. Şahruh onun üzerine İbrahim Caku'yu yolladı. İsfend Bey ise Muş ovasından kaçarak Cizre taraflarında bulunan ağabeyi İskender'in yanına gitti. ${ }^{58}$

Biraz önce Kadı Muhammed'i elçi olarak Şahruh'a gönderen Emir Şemseddin, Muş kale Hâkimi Abdurrahman ve bölgedeki bazı beyleri yanına alarak Erciş’ten Ahlat'a gelen Şahruh'un huzuruna bizzat çıkt1. ${ }^{59} 1421$ 'in yaz mevsimi başında gerçekleşen bu ziyaretten memnun kalan Şahruh, Bitlis hâkimine değerli hediyeler verdi. Ayrıca Şahruh, 1394'te Emir Timur'un Emir Şemseddin'e vermiş olduğu Bitlis'in idaresi hususundaki beratını yeniledi. Kısa süre sonra yurduna dönmesi için ona izin verdi (18 Haziran 1421). ${ }^{60}$

Şahruh, bölgede otoriteyi sağladığına inandıktan sonra Ahlat'tan Aladağ’a gelip buradan Tebriz’e dönmek istedi. Ancak Akkoyunlu Ali Bey ve Kara Yülük Osman Bey, Kara Koyunlu Mirzaların anlaşıp birleştiklerini ve Azerbaycan üzerine yürüyecekleri konusunda Şahruh’u ikna

53 Hâfız-1 Ebrû, C. 4, s. 725-726; Ca’ferî b. Muhammed el-Hüseynî, Târîh-i Kebîr (Tevârîh-i Enbiyâ ve Mülûk), (Çev. İsmail Aka), TTK Yayınları, Ankara 2011, s. 84; Sümer, Kara Koyunlular (Başlangıçtan Cihan-Şah'a Kadar), s. 110-112; İsmail Aka, "Şahruh'un Kara Koyunlular Üzerine Seferleri”, Tarih Incelemeleri Dergisi, C. 4, S. 1, İzmir 1989, s. 7-9; Hasan Taşkıran, "Tabiiyetten Çatışmaya Akkoyunlu Timurlu İlişkileri”, Ĭğır Üniversitesi Sosyal Bilimler Dergisi, S. 22, Nisan 2020, s. 317-318.

54 Şerefhan, C. I, s. 379; Hâfız-1 Ebrû, C. 4, s. 753; Sümer, Kara Koyunlular (Başlangıçtan Cihan-Şah'a Kadar), s. 118.

55 Ebû Bekr-i Tihrani, s. 60-63.

56 Şerefhan, C. I, s. 379.

57 Hâfız-1 Ebrû, C. 4, s. 767-774; Ca’ferî b. Muhammed el-Hüseynî, s. 85-86.

58 Hâfız-1 Ebrû, C. 4, s. 774; Aka, "Şahruh'un Kara Koyunlular Üzerine Seferleri", s. 10-11; Geyikoğlu, "Kara-Koyunlular'ın Van-Gölü Çevresindeki Faaliyetleri ve Günümüze Ulaşabilen Kültürel Mirasları", s. 216; Taşkıran, "Tabiiyetten Çatışmaya Akkoyunlu Timurlu İlişkileri”, s. 318-319.

59 Kemaleddin Abdurrezzak-i Semerkandî, C. II/I, s. 307-308.

60 Şerefhan, C. I, s. 379; Hasan-1 Rumlu, s. 138. Emir Şemseddin'in yanı sıra Muş Kale hâkimi Abdurrahman, İzzeddin Şir’in oğlu Melik Muhammed, Akkoyunlu Kara Yülük Osman'ın oğlu Emir Ali ve Bayezid Bey'de Şahruh'u ziyaret edenler arasındadır. Bkz.; Hâfız-1 Ebrû, C. 4, s. 775; Kemaleddin Abdurrezzak-i Semerkandî, C. II/I, s. 310. 
ederek dönüşünü ertelettiler. Nitekim birkaç gün sonra, "Bitlis'ten Kara Koyunlu geldi”, haberi Timurlu karargâhına ulaştı. Kara Koyunlu İskender ve İsfend kardeşler, Bitlis üzerinden Ahlat ve Adilcevaz önlerine kadar geldi. ${ }^{61}$ Aladağ'dan Erciş'e dönen Şahruh, öncü birliklerini Kara Koyunluların üzerine gönderdi. Adilcevaz yakınlarında mağlup olan Kara Koyunlu Mirzalar, Bulanık üzerinden Eleşkirt'e kadar geldiler. İskender ve İsfend Beyler, Şahruh'a barış için elçiler göndermişse de bu durum Şahruh tarafından kabul görmedi. Kısa süre sonra Şahruh ağırlıklarıyla birlikte yanında Akkoyunlu Ali Bey varken, Eleşkirt yakınlarındaki Ağa Deve mevkiine geldi. Buradayken Kara Yülük Osman Bey'e de haber gönderip bir an önce yanına gelmesini istedi. Kısa sürede Timurlu karargâhına ulaşan Osman Bey, Şahruh'u Kara Koyunlu Mirzalar konusunda kışkırtmaya çalıştı. ${ }^{62}$ Nitekim Timurlularla Kara Koyunlular, Ağa Deve yakınlarında Altın Bahşi/ Yahşi? ${ }^{63}$ denilen yerdeki şiddetli çarpışmada İskender ve İsfend Beyler ağır bir şekilde mağlup oldular (1 Ağustos 1421). ${ }^{64}$

Kara Koyunlu Mirzalar, yenilgiden sonra Musul ve Kerkük taraflarına çekilirken Şahruh ise önce Tebriz'e oradan da Horasan'a gitti. Kara Koyunlulardan boşalan bölgedeki kale ve yerleri Akkoyunlu Kara Yülük Osman Bey hâkimiyeti altına almaya çalıştı. Bu bağlamda Süleymani ve Zerki/Zırki Kürt aşiretlerin tabiiyetini sağlayan Osman Bey, bu aşiretlerin elindeki Meyyafarikin ve Tercil kaleleriyle birlikte 8 kaleyi daha aldı. Ayrıca Bitlis ve Ahlat'taki Kürt Rojki Beyleri ile Van ve Vestan/Vustan (Gevaş)' daki Beyleri kendisine bağladı. ${ }^{65}$

Şahruh'un bölgeden ayrılışını firsat bilen Kara Koyunlu İskender ve İsfend Beyler, hem Timurluları metbu kabul eden Akkoyunlulara kaptırmış olduğu yerleri geri almak hem de daha önce Kara Koyunlulara bağlı olup da Şahruh'a tabiiyet gösteren beyleri cezalandırmak için tekrardan Van Gölü havzasına geldiler. Tabi Kara Koyunlu mirzalar arasında da bir rekabet söz konusuydu. İskender Bey, Kerkük’ten kardeşi İsfend'in Akkoyunlu Ali Bey'den aldığ kardeşinden aldı. Kardeşine karşı koyamayacağını anlayan İsfend Bey, Tebriz'den Avnik'e oradan da Bağdat'a çekildi. Bir süre Tebriz'de kalan İskender Bey ise 1422'de Hoy'un batısında bulunan Sökmenâbad'a geldi. Yanında Çemişgezek hâkimi Şeyh Hasan da vardı. Şeyh Hasan, İskender Bey’i Akkoyunlulara karşı kışkırtarak onu Diyarbekir'e sefer düzenlemesi için ikna etti. Kara Koyunlu Bey’i Diyarbekir seferi için Erciş ve Ahlat yoluyla Çapakçur (Bingöl) yaylasına geldi. İskender Bey bölgeye geldiğinde eniştesi Bitlis hâkimi Emir Şemseddin'i ve Van hâkimi İzzeddin Şir'in oğlu Melik Ahmed'i yanına çağırdı. Bingöl'de ikamet eden İskender Bey, buradayken sürek avları tertipleyip eğlenceyle vakit geçirdi. Bir süre sonra yanında bulunan Emir Şemseddin ve Melik Ahmed'i tutuklattı. ${ }^{66}$ Diyarbekir seferini erteleyen İskender, yanına iki emiri alarak Bitlis önlerine gelerek şehri kuşattı. Bitlis, kale dizdarı Mihmad-1 Rojki tarafından savunulmaktaydı. İskender Bey, II. Emir Şemseddin ve Mihmand'ın oğlunu kalenin önüne gönderdi ve Emire baskıyla Bitlis Kalesi dizdarına kaleyi teslim etmesini emrettirdi. Ancak Mihmad-1 Rojki, Şemseddin'in emirindeki

61 Ebû Bekr-i Tihrani, s. 64; Ca’ferî b. Muhammed el-Hüseynî, s. 86.

62 Hâfız-1 Ebrû, C. 4, s. 777; Taşkıran, “Tabiiyetten Çatışmaya Akkoyunlu Timurlu İlişkileri”, s. 319-320.

63 Hasan-1 Rumlu, s. 139; Aka, "Şahruh'un Kara Koyunlular Üzerine Seferleri”, s. 11; Sümer, Kara Koyunlular (Başlanglçtan Cihan-Şah'a Kadar), s. 121-122.

64 Ebû Bekr-i Tihrani, s. 65-67; Aka, “Şahruh’un Kara Koyunlular Üzerine Seferleri”, s. 12; Aka, Mirza Şahruh ve Zamanı (1405-1447), s. 122-124.

65 Ebû Bekr-i Tihrani, s. 71.

66 Hasan-1 Rumlu, s. 145-146. 
sırra vakıf olup bunun bir tuzak olduğunu anladığı için bağlı olduğu bey ve oğluna rağmen Bitlis Kalesini teslim etmeyi ret etti. Rojkilerle kaleyi savunan Mihmand'i alt edemeyen İskender Bey, Emir Şemseddin'in birç̧ok adamını oracıkta öldürdü. Bitlis’ten ümidini kesen İskender, Emir Şemseddin'i yanında bu kez Ahlat'a götürdü. Burada da Bitlis'te olduğu gibi Rojki aşiretinden kimseler kalenin güvenliğini sağlamaktaydılar. Kara İskender, Bitlis önünde olduğu gibi Emir Şemseddin'i kalenin önüne getirerek onu kaledekilere gösterip Ahlat'1 almak istiyordu. Bitlis'te olduğu gibi Emir Şemseddin ileriye sürüldü. Emir Şemseddin akıllılık yaparak durumun tuzak olduğunu kaledekilere göstermek için kemerini çözüp geri bağladı. Emirin bundaki gayesi kaledeki askerlere burayı savunmalarını işaret etmekti. Nitekim askerler durumu anlayıp kaleyi savundular. Gizli işareti anlayan Kara Koyunlu İskender ise eniştesi Bitlis hâkimi Emir Şemseddin'i Ahlat kalesi önünde öldürdü (1422/1423). Buradaki muhkem kaleyi alamayacağını anlayan İskender, Kara Koyunlu askerlerinin bir kısmını muhasara için bıraktıktan sonra geri Bitlis önlerine geldi. Burada toy düzenledi. ${ }^{67}$ Kara İskender'in Ahlat çevresini vurmaları için görevlendirdiği askerler, bölgedeki Müslüman ahalinin yanı sıra gayrimüslim topluma da büyük zarar verdi. Mahalli Ermeni Kroniklerine bu durum yansımıştır. Özellikle Ahlat kuşatması sırasında Kara İskender, buradaki kaleyi alamayınca tüm şehri yaktı. Kara Koyunlu askerler, Ahlat çevresindeki Ağuvank (Ahlat'ın köyler bölgesi)'a gelip burayı aldılar. İskender'in adamları buradaki kaleyi zapt ettikten sonra bölgede yaşayan insanların birçokları suda boğuldu. Uçurumdan atılarak öldürdüklerinin dışında yaklaşık 200 gayrimüslimi kılıçtan geçirdiler. Bu sırada Hizan, Bitlis, Dzığak, Ağağ ve Ağet'ten bölgeye başak toplamak için gelen köylülerden 500 kişinin üzerindeki kadın ve çocukların çoğu esir alındı. İlgili Ermeni kroniği tüm yaşananların sebebi olarak gururuna yediremeyip İskender'e itaat etmeyen Bitlis Emiri Şemseddin'i göstermektedir. ${ }^{68}$

Şerefhan, büyük dedesinin öldürülme sebebi hakkında halk arasında dolaşan söylentiyi eserinde; "Emir, İskender'in kız kardeşi olan eşi Türkmen kızı olduğundan ata binmeyi, çevgaân (değnek) oynamak ve ok atmaktan çok hoşlaniyordu. Bitlis'te de bunlarl yapmak istedi. Ancak Emir buna izin vermedi. Emir, biz Kürdürler arasında Türkmenlerin geleneği hoş karşılanmaz, dediyse de eşine engel olamadi. Kadının dil uzatması ve hayâsızlı̆̆ yüzünden Emir Şemseddin kadının ăgzına bir yumruk vurarak bir dişini kırdı. Kadın kırık dişsini bir kâğıda sardı ve şikâyet mektubuyla birlikte Erciş̧'te bulunan kardeşine gönderdi. Pervasız zalim, Deli İskender diye ün yapmuştı. Çünkü Emir Şemseddin'i onu görmeye Ahlat'a gittiğinde onu öldürdü." şeklinde nakleder. Ancak müellif, satırlarının devamında bu rivayetin uzak bir ihtimal olduğunu Bitlis Emirinin öldürülmesinin sebebini onun Mirza Şahruh sarayına gönülden metbuluğuna dayandırmaktadır. Emir Şemseddin'in cesedi, bir rivayete göre Ahlat'tan Bitlis'e getirilerek Gök Meydanının doğu kısmında yaptırmış olduğu zaviyeye defnedilmiş diğere bir rivayete göre ise Ahlat'ta gömülmüştü. ${ }^{69} \mathrm{O}$, kendi adına altın gümüş karışımı bir miskal ağırlığında para basan ilk emirdir. ${ }^{70}$ Emir Şemseddin'in ölümünden

67 Ebû Bekr-i Tihrani, s. 72-73; Hrand D. Andreasyan, "XIV. ve XV. Yüzyıl Türk Tarihine Ait Ufak Kronolojiler ve Kolofonlar", Tarih Enstitüsü Dergisi, S. 3, İstanbul 1972, s. 103; Aka, Mirza Şahruh ve Zamani (1405-1447), s. 108.

68 Andreasyan, s. 88.

69 Şerefhan, C. I, s. 380-381.

70 Emir Şemseddin'in adına bastırdığı parayla ilgili Şerefhan, Türkmenlerin egemenliği ortadan kalktıktan sonra Emirin kendi adına para bastırıp hutbe okuttuğu, altın ve gümüş karışımı bir miskal ağırlığında üzerinde Şemseddin yazdığını, Kürdistan halkının bu parayı teberrük maksatlı sakladıklarını ve bu parayı gördüğünü eserinde nakletmektedir. Şerefhan, Şemseddin'in parası dışında Muhammed b. Şeref, 
sonra onun yerine Bitlis Emirliğinin başına oğlu Şeref geçti. Kendisi tuhaf bir kişiliğe sahip olup ilginç alışkanlıkları bulunmaktaydı. Geceleri hamam ocaklarında yatar gündüzleri ise özel olarak yaptırmış olduğu demir kafeste kalır ve sürekli “erkek kekliğin yeri kafestir” derdi. Zira Şeref b. Şemseddin'in iktidarı çok uzun sürmedi. ${ }^{71}$

Şeref b. Şemseddin'den sonra Bitlis Rojki Beyliği kısa süreliğine çözülüp bölgedeki Rojki valileri bağımsız hareket etmeye başladılar. Şerefhan'ın rivayetlere dayandırarak anlattığı bu evreyle ilgili yetersiz ve çelişkili bilgiler bulunmaktadır. Anlatılana göre; III. Şeref b. Şemseddin, Hasankeyf hükümdarlarının kızı olan Şahım hatun ile evliydi. Bu hatundan Şemseddin isminde küçük bir oğlu bulunmaktaydı. Şeref Bey, vefat edince adı geçen hatun Mir Seyid Ahmed ile evlendi. Şemseddin'in küçük olmasından dolayı Bitlis Beyliğinin idaresi Hatun ile eşinin eline geçti. Ancak Rojki aşiretinin ileri gelenleri bu duruma karşı çıkarak aşiret üyelerinin her biri beylik iddiasında bulunarak hâkim oldukları alanları kendileri idare etmeye başladı. Mir Muhammed Nasıruddin Ahlat'1 Abdurrahman Ağa Kavalisi ise Çukur ve Muş bölgelerini yönetti. Bir süre sonra Emir Şemseddin b. Şeref, idareyi ele alarak Rojki aşiretinin beylerini tekrardan kendi etrafinda toplamayı başardı. Kendisine muhalefet eden Bohtan hâkimi Mir Abdal ile barış tesis etti. ${ }^{72}$

Bitlis Beyliğindeki iktidar değişikliği sırasında Kara Koyunlu İskender Bey, Emir Şemseddin'i cezalandırdığı gibi kendisine samimi olarak bağlanmayan, Şahruh'a sadakat gösteren Van-Hakkâri hâkimi İzzeddin Şir'in oğlu Melik Ahmed'in üzerine yürüdü. Van önlerine gelen İskender Bey, Ahmed'i yakalamış olsa da dört ay boyunca kuşattığı şehrin kalesini alamadı. Kuşatma uzun sürünce İskender Bey, Ahmed'i yanında götürüp Alıncak Kalesine hapsetti. Kendisi de Tebriz'e geldi (1425). ${ }^{73}$ Yaklaşık bir yıl burada kalan Kara İskender, Ahmed'i öldürüp tekrardan Van önlerine gelerek şehrin kalesini kuşattı. Van’ın muhafızı Melik Esed'i mallarına karşı serbest bıraktı. Van'1 alan İskender Bey, buranın idaresine oğlu Yar Ali'yi getirdi. ${ }^{74}$ Ayrıca Melik Esed'in amcası Bahaddin'i de bertaraf eden Kara Koyunlu İskender Bey, böylece Van Gölünün doğu ve kuzey kesimlerinin tamamına hâkim oldu. ${ }^{75}$

Kara İskender'in faaliyet yahut sefer düzenlediği coğrafyalar ata yurdu olan yerlerin ötesine geçerek Timurlulara tabii bölgelere de saldırmaya başladı. Nitekim 1427-1428'de Şirvan seferine çıkan Kara Koyunlu Bey’i, Şemahi’yi yağmalayarak Tebriz'e döndü. 1429'da Sultaniye'yi alan İskender Bey, Şahruh'un valisi Hoca Yusuf'un elindeki Ebher, Kazvin ve Zencan'1 alıp komutanlarından Deli Ahmed ile Abdül'ün idaresine verdi. Azerbaycan ile ilgili bu haber Şahruh'a ulaşınca o, bir ordu toplayarak Kara İskender'i cezalandırmak için ikinci kez Azerbaycan tarafına

Şeref b. Muhammed ve Şemseddin b. Diyauddin adına basılmış üç farklı sikkeyi de gördüğünü belirtir. Bkz.; Şerefhan, C. I, s. 378-379

71 Şerefhan, C. I, s. 381.

72 Şerefhan, C. I, s. 381-386.

73 Sümer, Kara Koyunlular (Başlangıçtan Cihan-Şah'a Kadar), s. 127; Ermeni Kolofon sahibi Tuma Minas'ın Kara İskender'in Ahmed'i tutsak alması ve bölgedeki yoğun saldırıları için Bkz.; Andreasyan, s. 105-106, 108.

74 Hasan-1 Rumlu, İskender Bey’in Erbil kalesinin alındığını ve buranın idaresini oğluna verdiğini yazar. Bkz.; Hasan-1 Rumlu, s. 186.

75 Aka, Mirza Şahruh ve Zamanı (1405-1447), s. 140; Sümer, Kara Koyunlular (Başlangıçtan Cihan-Şah'a Kadar), s. 127; Geyikoğlu, "Kara-Koyunlular'ın Van-Gölü Çevresindeki Faaliyetleri ve Günümüze Ulaşabilen Kültürel Mirasları”, s. 219. 
sefere çıkt. ${ }^{76} 1429$ 'un baharında Herat'tan Rey'e doğru yola çıkan Şahruh, Tebriz'e gelene kadar bölgede çok sayıda kendisine askeri katılım oldu. Şahruh'un üzerlerine geldiğini duyan Kara Koyunlu İskender, iki kardeşi Cihanşah ve Ebu Said ile birlikte Urmiye'nin batısındaki Salmas'ta beklemekteydi. 17 Eylül 1429 'da karşı karşıya gelen iki ordu arasında üç gün boyunca yoğun çarpışmalar cereyan etti. 19 Eylül 1429 'da Kara Koyunlu Mirzalar yenileceklerini anlayınca Anadolu'ya girerek Van Gölü civarına geldiler. Târîh-i Kebîr'in kaydına göre; Kara İskender'in yenilerek Van tarafına kaçtığında yanındaki çok az bir birlikle Adilcevaz kalesini kuşattı. Bu haber Şahruh'a ulaşınca oğlu Mirza Cuki'yi İskender'in peşine gönderdi. Mirza Cuki yanındaki adamlarıyla Adilcevaz önlerine gelerek İskender Bey'i mağlup ederek kaçmaya mecbur bıraktı. ${ }^{77}$ Adilcevaz önlerinde Timurlulara tekrardan yenilen Kara İskender, bu kez Erzurum taraflarına kaçtı. Peşinden giden Mirza Cuki, onu yakalayamadı. Ondan geride kalan ganimetlerle birlikte bu sırda kışlak için Karabağ'a geçen Şahruh'un yanına gitti. Şahruh, Karabağ’ dayken yanına Kara Koyunlu İskender'in kardeşi Ebu Said, huzura gelerek itaat arz etti. Buna karşlık Şahruh, ona Tebriz'in idaresini verdi. Şahruh bölgeden ayrilınca Kara İskender, Tebriz üzerine yürüyerek 1431-1432'de kardeşi Ebu Said'i öldürdü. Buranın idaresini eline geçiren Kara İskender, Van ve çevresine daha önce olduğu gibi oğlu Yar Ali'yi atadi. ${ }^{78}$

Yar Ali'nin bölgeden haksız vergiler alması ve halka zulmetmesi, yöre halkının onu babasına şikâyet etmesine neden oldu. İskender Bey, oğlunu huzuruna çağırdığı halde oğlu ondan korkarak Şirvan'a kaçtı. Şirvanşah Halil ise İskender'den çekindiği için onu Semerkand'a gönderdi. Burada hapsedilen Yar Ali, firsatını bulup kaçarak Herat'a gelip isyan etti. Ancak saltanatını ilan eden Yar Ali çok geçmeden öldürüldü (1449) ${ }^{79}$ Kara İskender, Şirvanşahları cezalandırmak için çıktığı sefer öncesinde Yar Ali'den boşalan Van ve çevresinin idaresini kardeşi Cihan Şah'a verdi (1436). ${ }^{80}$

Kara Koyunlu ve Timurlular arasında cereyan eden çatışmalar sırasında Bitlis Beyliği dâhilinde saltanat değişiklikleri yaşanmaktaydı. Emir II. Şemseddin'in Ahmed, Mahmud, Diyadin, Şeref ve İbrahim adlarında beş oğlu vardı. İlk üç isim 1431/1432'deki veba salgınında ölmüşlerdi. ${ }^{81}$ Bu salgın hakkında ilgili Ermeni kronikleri sebebini Şahruh'a bağlasa da yaşananları; "Bu acıklı zamanda o kadar şiddetli bir açlık oldu ki insanlar mekruh hayvanlart yediler ve Tebriz'de insan eti satıld" " gibi abartılı ifadelerle ortaya koymaktadır. ${ }^{82}$ Bahse konu olan Şemseddin'in üç oğlundan geride kalan diğer ikisinden Şeref, gençken vefat etmiş ve bir tek İbrahim kalmıştı. Böylece Bitlis Beyliğinin başına Emir Şemseddin (1431)'den sonra oğlu I. İbrahim geçti. ${ }^{83}$ I. İbrahim'in beyliği zamanında Bitlis'in hemen kuzey doğusunda Timurlu Kara Koyunlu mücadeleleri devam

76 Sümer, Kara Koyunlular (Başlangıçtan Cihan-Şah'a Kadar), s. 127.

77 Ca’ferî b. Muhammed el-Hüseynî, s. 92. Ayrıca Bkz.; Hasan-1 Rumlu, s. 199.

78 Şerefhan, C. II, s. 90-91; Ca’ferî b. Muhammed el-Hüseynî, s. 93; Hasan-1 Rumlu, s. 204; Aka, Mirza Şahruh ve Zamanı (1405-1447), s. 142-143, 149; Sümer, Kara Koyunlular (Başlangıçtan Cihan-Şah'a Kadar), s. 131-132; Aka, Iran'da Türkmen Hâkimiyeti (Kara Koyunlular Devri), s. 19-20; Aka, "Şahruh'un Kara Koyunlular Üzerine Seferleri”, s. 12-13; Taşkıran, "Tabiiyetten Çatışmaya Akkoyunlu Timurlu İlişkileri", s. 322.

79 Sümer, Kara Koyunlular (Başlangıçtan Cihan-Şah'a Kadar), s. 133.

80 Hasan-1 Rumlu, s. 204; Mükrimin Halil Yinanç, "Cihan-Şah”, İ.A., C. 3, MEB Yayınları, İstanbul 1945, s. 173 .

81 Şerefhan, C. I, s. 387.

82 Andreasyan, s. 111.

83 Şerefhan, C. I, s. 387. 
etmekteydi. Şahruh, Şirvan seferi için Kara İskender'in cezalandırmak adını 1434-1435'te üçüncü kez Azerbaycan Seferine çıtı. Rey'deyken Van bölgesi hâkimi Kara Koyunlu Cihanşah'ı huzuruna çağırdı. Cihanşah, onun yanına giderek itaat arz etti. Buna karşılık Şahruh, daha önce İskender ile problem yaşayan Cihanşah'a Azerbaycan'ın idaresini verdi. ${ }^{84}$

Şahruh, Kara İskender'in üzerine yürüdüğünde Kara Koyunlu Bey’i Şirvan'dan Alıncak'a gelmişti. Şahruh yine Mirza Cuki'yi onun üzerine gönderince Kara İskender, ağırlıklarını bırakarak Anadolu'ya çekildi. Çünkü o, Erzurum üzerinden Osmanlı toprağına geçmek istiyordu. Bunu öğrenen Şahruh, kendisine bağl1lık bildiren Akkoyunlu Kara Yülük Osman'a haber göndererek İskender'in yolunu kesmesini istedi. İskender'in önünü kesen Osman Bey, Erzurum yakınlarındaki Döşkaya mevkinde onunla karşı karşıya geldi. ${ }^{85} \mathrm{Bu}$ karşılaş̧mada Akkoyunlular birçok kayıp vererek mağlup oldu. Arkasından Mirza Cuki’nin geldiğini duyan İskender, Erzurum'da kalmayarak Osmanlı Sultanı II. Murad'a sığındı. ${ }^{86}$

Şahruh, Horasan'a döndükten sonra İskender Bey, Osmanlı ülkesinden dönerek kardeşi Cihanşah'ın üzerine Tebriz'e yürüdü. Tebriz'i kuşattı fakat alamadı. Kardeşiyle Sufiyan mevkiinde Heft Çeşme-i denilen yerde girdiği mücadeleyi kaybederek Alıncak'a sığındı. İskender buradayken oğlu Şah Kubad tarafindan ailevi bir meseleden ötürü öldürüldü (1438). ${ }^{87}$ İskender Bey ölünce Kara Koyunluların başına Cihanşah (1438-1467) geçti. ${ }^{88}$

\section{Kara Koyunlu ve Akkoyunlu Mücadele Sahası Olarak Bitlis ve Çevresi}

Kara Koyunlulardaki taht değişikliği sırasında Bitlis Emirliğinde de değişiklikler meydana geldi. Bitlis Rojki Emiri I. İbrahim'in akabinde oğlu Hacı Muhammed (1443-1460) onun yerine geçti. Hacı Muhammed dönemi Bitlis ve çevresi mamur hale getirildi. O, 1444'te Bitlis nehri kıyısında kervansaray medrese ve cami yaptırdı. İlgili Bey'in İbrahim ve Şemseddin isminde iki oğlu bulunmaktaydı. Hacı Muhammed, 1460’ta vefat edince yerine oğlu II. İbrahim geçti. Akkoyunlularla Kara Koyunluların bölgede varlık mücadelesi verdiği dönemde İbrahim'in iktidarı yaklaşık 7 yıllık sürdü. Ardından kardeşi Şemseddin (1467-1494)'in Akkoyunluların gölgesinde uzun bir yönetim dönemi başladi. ${ }^{89}$

Kara Koyunlu Cihanşah ile Akkoyunlu Uzun Hasan Bey'in rekabeti genel olarak Bitlis ve Ahlat'ın yer aldığı Van Gölü havzasında cereyan etmekteydi. Esasında Akkoyunlular bölgeye hükmedince Kara Koyunlular, idarelerinden çıkan yerleri geri almak için bölgedeki yerel beylere

84 Devletşah Semerkandî, Tezkiretü 'ş-Şuara, C. III, (Çev. Necati Lugal), Kervan Yayınları, İstanbul 1977, s. 458; İdris-i Bitlisi, Heşt Bihişt, C.II, (Haz. Mehmed Karataş, Selim Kaya, Yaşar Baş), Bitlis Eğitim Tanıtma Vakfı, Ankara 2008, s. 317; Taşkıran, "Tabiiyetten Çatışmaya Akkoyunlu Timurlu İlişkileri”, s. 323.

85 Ebû Bekr-i Tihrânî, s. 79-84; Ca'ferîb. Muhammed el-Hüseynî, s. 102-103; Gürsoy Solmaz, "Akkoyunlar'ın Kara Koyunlar’a Karşı Döşkaya Saldırısı”, A.Ü. Türkiyat Araştırmaları Enstitüsü Dergisi, S. 37, Erzurum 2008, s. 241-246; Taşkıran, “Tabiiyetten Çatışmaya Akkoyunlu Timurlu İlişkileri”, s. 323-325.

86 Ebû Bekr-i Tihrânî, s. 85.

87 Sümer, Kara Koyunlular (Başlangıçtan Cihan-Şah'a Kadar), s. 139-140.

88 Ebû Bekr-i Tihrânî, s. 98; İdris-i Bitlisi, s. 317-3 18.

89 Şerefhan, C. I, s. 387. 
saldırıp onları cezalandırarak otoritelerini sağlamaktaydılar. Bu mücadeleler sırasında mahalli idare merkezleri Bitlis, Ahlat, Muş ve Van gibi şehirlerdeki yöneticiler çok sık taraf değiştirmek zorunda kalmaktaydılar. Bu değişiklikler Bitlis hâkimi Emir II. İbrahim ve Emir Şemseddin Şeref kardeşler döneminde yoğun olarak yaşanmaktaydı. Cihanşah, Timurluların desteğiyle Kara Koyunluların başına geçtiğinden itibaren Bitlis ve Ahlat Beyleri önceki dönemlerde olduğu gibi Kara Koyunlulara tabiiyetini sürdürmekteydiler. Bu tabiiyet Akkoyunlu Uzun Hasan Bey döneminden itibaren zayıflamaya başladı.

Bilindiği üzere Timurlu hükümdarı Şahruh, 1447'de vefat ettikten sonra Timurlu mirzalar kendi aralarında saltanat için mücadeleye giriştiler. Kara Koyunlu Cihanşah ise hem hâkimiyet sahasını genişletmek hem de Timurlular üzerinde nüfuzunu artırmak için mirzaların bazılarının yanında yer aldı. Diyarbekir'den Azerbaycan'a kadar olan bütün topraklara hükmeden Cihanşah, Şahruh sonrası bağımsız hareket ederek hakanlığını ilan etti. Ancak kısa süre sonra kardeşi ve oğullarının kendisine isyan etmesi onu zayıflattı. Cihanşah'ın Kara Koyunlu iç isyanlarıyla meşgul olduğu sıralarda Akkoyunlu Uzun Hasan Bey, ağabeyi Cihangir'den Diyarbekir'i aldı (1452). ${ }^{90}$ Sonraları hâkimiyet alanını Amid'den Erzincan ve Bayburt'a kadar genişleterek Cihanşah'ın otoritesine karş1 Anadolu'da en önemli muhalefeti gösterdi. ${ }^{91}$

Uzun Hasan Bey, 1452/53'de Diyarbekir'i alınca Van Gölü havzasındaki mahalli idarecilerin ehemmiyetini anlayarak Bitlis, Ahlat ve çevresiyle ilgilenmeye başladı. Öyleki Bitlis Emirleri, Kara İskender döneminden itibaren Kara Koyunluların bölgeye yönelik yağma, talan ve istilalarını unutmadıkları için Van Gölü havzasıyla ilgilenen Uzun Hasan Bey'e kolaylıkla intisap etmişlerdi. ${ }^{92}$

1456'da Uzun Hasan Bey'e karşı ağabeyi Cihangir tekrardan isyan edip Mardin taraflarına kaçmıştı. Bu sırda Kara Koyunlu Cihanşah'tan da yardım talep etmişti. Kara Koyunlu hükümdarı ise yardım için Emir Rüstem Bey’i Cihangir'e gönderdi. Ancak 1457'de Fırat kenarında Uzun Hasan Bey, Kara Koyunluları mağlup ederek Rüstem Bey’i öldürdü. Sonra Mardin'e gelip ağabeysinin isyanını bastırdı. ${ }^{93}$ Kara Koyunlu Cihanşah, Timurlulara son vermek için Horasan taraflarına gidince Uzun Hasan Bey, hiç vakit kaybetmeden Kara Koyunluların elindeki Erzincan'a saldırdı. Burayı alarak amcasının oğlu Hurşid Bey’e verdi. Buradan Van Gölü havzasına yönelen Hasan Bey, Bingöl yaylağına gelerek kardeşi Cihanşah Bey komutasında kuvvetleri Ahlat, Adilcevaz ve Erciş taraflarına yağmaya gönderdi. Bu sırda Ahlat tarafında başka bir Akkoyunlu birliği yaklaşık olarak 20 bin kişilik Kara Koyunluları yağmalayarak bir çoklarını yakalamış ve ganimet elde etmişlerdi. ${ }^{94}$

Bitlis ve yöresi, Cihanşah ve Uzun Hasan arasındaki rekabete maruz kalan önemli bir bölgeydi. Bir yandan Kara Koyunlular diğer yandan Akkoyunluların saldırıları bölgedeki mahalli

90 Ebû Bekr-i Tihrânî, s. 151.

91 İsmail Hakkı Uzunçarşıl1, Anadolu Beylikleri ve Akkoyunlu, Karakoyunlu Devletleri, TTK Yayınları, Ankara 2011, s. 190-191; İlhan Erdem, Kazım Paydaş, Ak-Koyunlu Devleti Tarihi (Siyaset, Teşkilat, Kültür), Birleşik Yayınevi, Ankara 2007, s. 77-84.

92 İlhan Erdem, "Akkoyunlular Devrinde Bitlis ve Yöresi: Genel Bir Değerlendirme", Tarihi ve Kültürel Yönleriyle Bitlis, C. I, (Editör: Mehmet İnbaşı, Mehmet Demirtaş), Bitlis Eren Üniversitesi Yayınları, Ankara 2019, s. 142.

93 V. Minorsky, "Uzun Hasan”, İA, C. XIII, MEB Yayınları, İstanbul 1986, s. 91-92; Faruk Sümer, “Uzun Hasan”, DIA, C. 42, TDV Yayınları, İstanbul 2012, s. 262.

94 Ebû Bekr-i Tihrânî, s. 149-151. 
idareci ve Müslüman halkın yanı sıra gayrimüslim halk da etkilenmiştir. Ermeni Kolofonların aktardıklarına göre Cihanşah zamanında Kara Koyunlular bölge halkına büyük zararlar vermişti. Bu cümleden olmak üzere 1461/62'de Cihanşah, Kara Koyunlulara vermesi gereken vergiyi göndermeyen Bitlis Emiri Şerif (Şerif olarak bahsettiği kişi II. İbrahim b. Hacı Mehmed'dir)'e kızarak Ahlat ve Bitlis üzerine 12 bin kişilik bir kuvvet sevk etti. Ahlat'ı yağmalayan Kara Koyunlular, Bitlis'in yöresindeki diğer yerleşim yerleri, Khut (Mutki), Muş ve Sasun/Sason'u tahrip ederek büyük ganimetler elde ettiler. Akabinde Bitlis önlerine gelerek şehrin kalesini kuşattılar. Kara Koyunlular, başta Bitlis olmak üzere Ahlat ve Muş’tan, muhtemelen bölgedeki Hristiyanlardan, kadın, erkek ve din adamının yer aldığı 1500 esir alarak her birini 500 tuman'a satmışlardı. Kara Koyunlu birlikler bunu yaparken Cihanşah ise Bitlis Emiri Şerif (II. İbrahim b. Hacı Mehmed)'i azlederek yerine amcasının oğlu Emir Şemseddin (muhtemelen kastedilen kişi II. İbrahim'in kardeşi Emir Şemseddin Şeref'tir)'i tayin etti. ${ }^{95}$ Yöredeki halkın perişan durumuna üzülen Katolikos Zakarya, Cihanşah'ın huzuruna giderek halkın yerine kendisini esir almasını, ayrıca Bitlis Emiriyle meselesini adaletle çözmesini, Bitlis’ten gerekli vergiyi alıp getirmesi için kendisine bir salahiyet yazısı vermesini teklif etti. Kara Koyunlu Hükümdarı Cihanşah, yapılan bu teklifi kabul ederek ona salahiyet yazısı vererek Bitlis'e gönderdi. Bitlis Emiri, Kara Koyunluların Ahlat'tan çekilmesi şartıyla Cihanşah'a vergi vermeyi kabul etti. Bitlis Emirinden gerekli sözü alan Katolikos, Ahlat'a giderek Kara Koyunlu komutanlarına Cihanşah'ın kendisine vermiş olduğu salahiyet yazısını gösterip onların Ahlat kalesini boşaltarak Cihanşah'ın yanına gitmelerini sağladı. Daha sonra Ahlat'tan Bitlis'e dönen Katolikos, burada üç ay kaldıktan sonra Bitlis Emirinin söz verdiği vergiyi alıp Cihanşah'a götürdü. ${ }^{96}$

Uzun Hasan Bey, giderek güçlenince Kara Koyunlu Cihanşah'ın dikkatini çekmekteydi. Nitekim Akkoyunlu Bey'i Diyarbekir önünde Kara Koyunlu Rüstem Tarhan'ı öldürmüş, Cihanşah'a muhalefet eden Şeyh Cüneyd'i himaye ederek onunla akrabalık bağ 1 kurmuştu. ${ }^{97}$ Caterino Zeno'un belirttiği üzere "İran hâkimi Cihanşah'a karşı Hasan Bey küçük kalenin sahibi" Bu tehlikeyi ortadan kaldırmak için Cihanşah, 1467'de Tebriz'den Diyarbekir üzerine yürümek için harekete geçti. Saadet ve ikbal, davul ve bayrak ile askersiz yola çıkan Cihanşah, önce Hoy yakınındaki Sökmen Ova (Sökmenâbâd)'ya gelip kondu. Burada eğlenceye daldı. Bu sırda Cihanşah'ın üzerine yürüdüğünü duyan Uzun Hasan, ağırlıklarıyla birlikte onu karşılamak için harekete geçti. Hasan Bey'in 12 bin kişilik bir orduyla Kara Koyunluları karşılamaya çıktığı haberini Adilcevaz hâkimi Mahmud-i Mihmandar, Cihanşah'ın karargâhına getirdi. Eğlenceye daldığı için kimse bu haberi Cihanşah'a söyleyemedi. En sonunda ertesi gün nedimlerden ve sırdaşlardan olan Kadı Abdullah, Uzun Hasan'ın haberini ona iletti. Bunun üzerine Cihanşah ailesini güvenli bir yer olan Buban Kalesine gönderdi. Bu sırda Hasan Bey, Harput önlerinde ordugâhını kurmuştu. Karş1lıklı elçilerin gidip gelmesi bir netice vermeyince Cihanşah, Sökmen Ova (Sökmenâbâd)'dan hareket edip Erciş’e geldi. Ama öncesinde bölgeye öncü olarak gönderilen Kara Koyunlu askerleri, İskender-i Pilten ve yanındaki bahadırlar tarafından Ahlat ve Muş arasındaki Şeyh İdris mevkiinde mağlup edildiler. Akkoyunlular, bunların arasından birini haber almak için esir alıp ordugâha

95 Andreasyan, s. 128.

96 Andreasyan, s. 131-132.

97 Erdem, Paydaş, s. 88.

98 Tufan Gündüz, Uzun Hasan ve Fatih Mücadelesi Döneminde Doğu'da Venedik Elçileri, Caterino Zeno ve Amrogioa Contarini 'nin Seyahatnameleri, Yeditepe Yayınevi, İstanbul 2006, s. 17. 
götürdüler. ${ }^{99}$ Burada bir süre kalan Kara Koyunlu Bey'i, oğulları ve askerlerini topladıktan sonra Adilcevaz ve Ahlat üzerinden önce Muş ovasına sonra da Çapakçur (Bingöl) yaylağına geldi. Yaz aylarının sonu olması nedeniyle Kara Koyunlu Emir ve askerler, kışlağa dönüp seferi bahara bırakma konusunda baskı yapmaya başladılar. Nitekim Cihanşah, yazlık eşyalarla gelen askerlerin bir kısmına Adilcevaz, Erciş ve Van'da kalmalarına, bir kısmına da Malazgirt üzerinden Aras kışlağına gitmelerine müsaade etti. Cihanşah ise Çapakçur'dan Kiğı'ya oradan da Sancak'a geldi. Buradayken Uzan Hasan Bey, birlikleriyle gece vakti Cihanşah ve askerlerine saldırdı. Kaçmaya çalışan Cihanşah, Uzun Hasan Bey'in adamı tarafından yakalanarak öldürüldü (11 Kasım 1467). ${ }^{100}$ Cihanşah'ın ölümünden sonra oğlu Hasan Ali Bey, Kara Koyunluların başına geçti. Ancak onun iktidarı da uzun sürmedi. 1468'te öldükten sonra Kara Koyunlu devleti tarih sahnesinden çekildi. Böylece Akkoyunlular, Diyarbekir'den Tebriz'e kadar olan coğrafyaya hükmetmeye başladı.

Kara Koyunlular yıkıldıktan sonra Uzun Hasan Bey, Kara Koyunlulara tabii bölgedeki mahalli yönetimleri kendisine bağlamaya çalıştı. 1469/1470'te Irak'1 alıp oradan Azerbaycan'a geçen Hasan Bey, Tebriz, Sultaniye'de konakladı. Bölgedeki Rüstemdarlıların itaatini sağladıktan sonra Kürdistan Kalelerin fethi için harekete geçti. Akkoyunlu emirler ve askerlerini önce Bohti vilayetine gönderdi. Buradaki Kürt aşiretini itaate çağırdıysa da bunlar bağlılıktan kaçındılar. Nihayetinde Hasan Bey, Şehzade Hamza-i Ciahngir'i Amid darugası Sultan Ahmed, Birecik darugası Rüstem Fahrüddin, Şah Ali, Sincar hâkimi, Hüsyin Bey Halil, Musul hâkimi Şemseddin Pir Hacı gibi emir ve beyleri 5 bin süvariyle birlikte Cizre şehrini kuşatmaya gönderdi. Akkoyunlu ordusu Cizre'yi alarak Sak/Şah kalesini kuşattılar. Kale hâkimi Bedru Beg (Emir Abdal'ın oğullarından Cizre hâkimi Emir Bedri), kuşatmadan kurtulamayacağını anlayınca kaleyi teslim etti. ${ }^{101}$

Cizre'nin yanı sıra Hasan Bey, daha önce Kara Koyunlulara bağlı bulunan Bitlis'in üzerine ordu gönderdi. Çünkü Akkoyunlu askerleri Kara Koyunlu Hasan Ali’nin üzerine sefere çıtıkları zaman Bitlis Emiri II. İbrahim muhalefet ederek Muş’ta bulunan askeri birliklerini Kara Koyunlulara destek için göndermişti. Başta Süleyman Biçen Bey olmak üzere Aslan Bey, Kızıl Ahmed Bey, Çepni İl Aldı Bey, Emir Muhammed Saadlu, Emir Can Saadlu, Saru Pir Ali'nin oğlu ve Şah Muhammed Duharlu gibi Akkoyunlu Beyleri 5 bin süvariyle birlikte Bitlis'i kuşatmaya geldi. Şehir ve Bitlis kalesi uzun süre kuşatma altında kaldı. Daha fazla dayanamayan ve şehri saldırılardan kurtarmak isteyen Bitlis Emiri II. İbrahim Bey, annesini ve vezirini kıymetli hediyelerle birlikte barış için Uzun Hasan Bey'in otağına gönderdi. Akkoyunlu hükümdarı bunun üzerine Bitlis Emiri II. İbrahim'i affederek şehrin kuşatmasını kaldırtıp orduyu geri çağırdı. Ordunun bir kısmını Halil Bey Pilten'in komutasında Muş’u kuşatmaya gönderdi. Ayrıca Kiğı'daki birliklerini de İskender Bey ve Ebubekir Duharlu ile birlikte Ahlat'1 kuşatmaya gönderdi. ${ }^{102}$ Şeref Han, Akkoyunluların yaklaşık olarak 3 yıl boyunca Bitlis Kalesini kuşattığını belirtmektedir. Uzun süre kuşatma altındaki kale ve şehirde kıtlık ile hastalığın baş göstermesinden dolayı II. İbrahim Bey'in anlaşma yoluna

99 Hasan-1 Rumlu, s. 435-439; Erdem, Paydaş, s. 88-89.

100 Ebû Bekr-i Tihrânî, s. 276-282; Hasan-1 Rumlu, s. 440-442; Sümer, "Karakoyunlular," s. 437; Aka, İan'da Türkmen Hâkimiyeti (Kara Koyunlular Devri), s. 70-71; Erdem, Paydaş, s. 90-92; Ayşe Atıcı Arayancan, Karakoyunlu Hükümdarlarından Cihânşah ve Dönemi (Siyaset-Teşkilat-Ikktisat-Din-Kültür) 1438-1467, Ankara Üniversitesi Sosyal Bilimler Enstitüsü, (Basılmamış Doktora Tezi), Ankara 2010, s. 184-186.

101 Ebû Bekr-i Tihrânî, s. 353-354.

102 Hasan-1 Rumlu, s. 492; Ebû Bekr-i Tihrânî, s. 354. 
başvurduğunu aktarmaktadır. ${ }^{103}$ Ayrıca Akkoyunlu birlikleri, uzun süre Kara Koyunlulara tabii olan bu şehirleri hâkimleriyle birlikte Uzun Hasan Bey’e tabii kıldılar. Böylece Bitlis Emirlerinin 29 yıllık Akkoyunlulara bağlılıkları başlamış oldu.

Uzun Hasan Bey'in 1478'de ölümünden sonra Akkoyunluların içine düştüğü saltanat mücadelesinden dolayı Bitlis Emirliği yeniden güçlenerek Akkoyunlu otoritesinden kurtuldu. ${ }^{104}$ 1498'de Bitlis Emirlerinden Şah Muhammed Bey, Bitlis kalesini Akkoyunlardan alarak burada idaresini tesis etti. ${ }^{105}$

1508 'de Safevilerin kurucusu Şah İsmail, Akkoyunlulara son verdikten sonra başta Azerbaycan olmak üzere Irak, Van Gölü havzası, Mardin ve Diyarbekir'e kadar Akkoyunluların hükmettikleri toprakları ele geçirdi. Aynı tarihte Bitlis hâkimi IV. Şeref Han, bazı Kürt beyleriyle birlikte Şah İsmail'e tabiiyet için Hoy'a gitti. Şah İsmail, IV. Şeref Han ve yanındaki diğer beyleri tutuklatıp Tebriz'de hapsetti. Daha sonra Bitlis'i istila için Çiyan (Çapan) Sultan’1 görevlendirdi. Adı geçen Bey, Bitlis önlerine gelerek şehri kuşattı. Bu sırada IV. Şeref Han'ın amcasının oğlu Emir İbrahim b. Şah Muhammed, iki yıl boyunca kaleyi savundu. İki yıllık savunmanın ardından kalede erzak ve iaşe bitiminden dolayı Emir İbrahim, daha fazla direnemeyeceğini anlayınca kaleden gizlice kaçıp Siirt taraflarına gitti. İbrahim'in firarından sonra geride kalan Rojki beyleri, Bitlis kalesini yaklaşık 6 ay savunduktan sonra burayı Çiyan (Çapan) Sultan'a teslim etmek zorunda kaldılar. Çiyan (Çapan) Sultan burayı yanında yer alan bir Kürt Beyine (Şarklı Ustaclu) verdikten sonra şehirden elde ettiği ganimetlerle Tebriz'e döndü. ${ }^{106}$

\section{Sonuç}

XV. Asırda Bitlis ve çevresi farklı güçlerin hâkimiyet kurmak isteklikleri bir yerdi. Bitlis merkezli mahalli Kürt Rojki Beyliği, sahip olduğu Bitlis ve Ahlat hattındaki bölgeyi başta Timurlular olmak üzere Kara Koyunlu ve Akkoyunlulara karşı muhafaza etmeye çalışmıştır. Bitlis Beyleri bunu bazen güçlü diplomasiyle bazen de akrabalık bağlarıyla yaptılar. Öyleki Emir Timur, 1394'te Van Gölü Havzasına geldiğinde Bitlis Emirlerinden Hacı Şeref, onu ziyaret ederek kıymetli hediyelerle tabiiyetini bildirdi. Yine Hacı Şeref'in oğlu Emir Şemseddin ise Timurluları bölgede meşgul eden Kara Koyunlu lideri Kara Yusuf'un kızıyla evlenip akrabalık bağıyla Kara Koyunlulardan Bitlis'i korudu. Ancak Van Gölü havzasında Timurlu-Kara Koyunlu ve AkkoyunluKara Koyunlu mücadelelerinden dolayı Bitlis Emirleri sık sık taraf değiştirmek zorunda kaldılar. Bundan dolayı Bitlis Emirlerinden bazıları bunu canıyla ödediler. Örneğin Emir Şemseddin'in Timurlulara karşı kayınbiraderi Kara İskender'e askeri destek sağlamamasından dolayı İskender onu 1422/23'te öldürdü.

Genel olarak Timurlulara bağlılı̆̆ını muhafaza eden Bitlis Beyleri, Şahruh'un ölümünden

103 Şeref Han bu hadiseyi 1466 tarihinde yaşandığını yazarak diğer dönemin kaynakları Ebû Bekr-i Tihrânî ve Hasan-1 Rumlu'un belirtikleri 1469 tarihi ile çelişmektedir. Bu hadise II. İbrahim'in saltanatının son y1l1 1467/68 tarihinde cereyan etmiştir.

104 Sümer, "Uzun Hasan”, s. 261-264.

105 Şerefhan, C. I, s. 396-397.

106 Şerefhan, C. I, s. 407; Abdullah Demir, "16. Yüzyılda Safevi ve Osmanlı Hâkimiyetinde Arşiv Belgeleri Işı̆̆ında Bitlis Beyleri”, I. Uluslararası Dünden Bugüne Tatvan ve Çevresi Sempozyum Bildirileri, Beyan Yayınları, İstanbul 2008, s. 258-259. 
sonra Kara Koyunlulara tabiiyet arz etmek durumunda kaldılar. Ancak Bitlis'in mahalli idarecileri bu kez ezeli rakipler Akkoyunlu ve Kara Koyunluların hâkimiyet mücadele sahası içerisinde kaldı. XV. Asrın ilk yarısında Timurlulara bağlılıklarından dolayı Kara Koyunluların vurduğu Bitlis Rojki Beyliği, XV. Asrın ikinci yarısından itibaren ise Kara Koyunlulara bağlılı̆̆ından dolayı Akkoyunlular tarafından istilaya maruz kaldı. Adı geçen devletlerin genelde Van Gölü Havzası özelde ise Bitlis ve çevresindeki hâkimiyet mücadelelerinde yerel beylerin yanı sıra en çok etkilenen ve kayıp verenler yörede yaşayan Müslüman ve Gayrimüslim halk oldu. Netice itibariyle tüm mücadele, istila ve kayıplara rağmen Bitlis ve çevresine hükmeden hâkim güçlerin hiç biri ne Bitlis'ten ne de Bitlis'i idare eden Hacı Şeref b. Diyadin'in evlatlarından vazgeçebildiler.

\section{Kaynakça}

Aka, İsmail, "Şahruh'un Kara Koyunlular Üzerine Seferleri”, Tarih İncelemeleri Dergisi, C. 4, S. 1, İzmir 1989, s. 1-20.

Aka, İsmail, İran'da Türkmen Hâkimiyeti (Kara Koyunlular Devri), TTK Yayınları, Ankara 2001.

Aka, İsmail, Mirza Şahruh ve Zamanı (1405-1447), TTK Yayınevi, Ankara 1994.

Aka, İsmail, Timur ve Devleti, TTK Yayınları, Ankara 2014.

Alan, Hayrunnisa, Bozkırdan Cennet Bahçesine Timurlular 1360-1506, Ötüken Neşriyat, İstanbul 2015.

Alikılıç, Dündar, Abbasî Devleti'nden Hakkâri Beyliği'ne İrisân Beyleri, Tarih Düşünce Kitapları, İstanbul 2006.

Andreasyan, Hrand D., "XIV. ve XV. Yüzyıl Türk Tarihine Ait Ufak Kronolojiler ve Kolofonlar”, Tarih Enstitüsü Dergisi, S. 3, İstanbul 1972, s. 83-148.

Atıcı Arayancan, Ayşe, Karakoyunlu Hükümdarlarından Cihânşah ve Dönemi (SiyasetTeşkilat-İktisat-Din-Kültür) 1438-1467, Ankara Üniversitesi Sosyal Bilimler Enstitüsü, (Basılmamış Doktora Tezi), Ankara 2010.

Aziz b. Erdeşir-i Esterâbadî, Bezm u Rezm, (Çev. Mürsel Öztürk), Kültür Bakanlığı Yayınları, Ankara 1990.

Ca’ferî b. Muhammed el-Hüseynî, Târîh-i Kebîr (Tevârîh-i Enbiyâ ve Mülûk), (Çev. İsmail Aka), TTK Yayınları, Ankara 2011.

Coşkun, Derya, "Tebriz'de Kurulan Feodal Bir Devlet: Revvâdiler (948/1071)", Tarihin Peşinde Uluslararası Tarih ve Sosyal Araştırmalar Dergisi, S. 23, 2020, s. 1-23.

Cüveynî, Tarih-i Cihan Güşa, (Çev. Mürsel Öztürk), TTK Yayınları, Ankara 2013.

Demir, Abdullah, "16. Yüzyılda Safevi ve Osmanlı Hâkimiyetinde Arşiv Belgeleri Işı̆̆ında Bitlis Beyleri”, I. Uluslararası Dünden Bugüne Tatvan ve Çevresi Sempozyum Bildirileri, Beyan Yayınları, İstanbul 2008, s. 253-283.

Devletşah Semerkandî, Tezkiretü'ş-Şuara, C. III, (Çev. Necati Lugal), Kervan Yayınları, İstanbul 1977. 

2014.

Ebû Bekr-i Tihrani, Kitab-ı Diyarbekriyye, (Çev. Mürsel Öztürk), TTK Yayınları, Ankara

Erdem, İlhan, “Akkoyunlu Devleti'nin Kurucusu Kara Yülük Osman Bey'in Hayatı ve Faaliyetleri”, Dil ve Tarih Coğrafya Fakültesi Dergisi, C. XXXIV, S. 1-2, Ankara 1990, s. 99-108.

Erdem, İlhan, “Akkoyunlular Devrinde Bitlis ve Yöresi: Genel Bir Değerlendirme”, Tarihi ve Kültürel Yönleriyle Bitlis, C. I, (Editör: Mehmet İnbaşı, Mehmet Demirtaş), Bitlis Eren Üniversitesi Yayınları, Ankara 2019, s. 139-143.

Erdem, İlhan, Paydaş, Kazım, Ak-Koyunlu Devleti Tarihi (Siyaset, Teşkilat, Kültür), Birleşik Yayınevi, Ankara 2007.

Geyikoğlu, Hasan, “Kara-Koyunlular'ın Van-Gölü Çevresindeki Faaliyetleri ve Günümüze Ulaşabilen Kültürel Mirasları”, Türkiyat Araştırmaları Enstitüsü Dergisi, S. 38, Erzurum 2008, s. 207-226.

Gregory Abû'l-Farac, Abû'l-Farac Tarihi, C. II, (Çev. Ömer Rıza Doğrul), TTK Yayınları, Ankara 1987.

Gündüz, Tufan, Uzun Hasan ve Fatih Mücadelesi Döneminde Doğu'da Venedik Elçileri, Caterino Zeno ve Amrogioa Contarini ‘nin Seyahatnameleri, Yeditepe Yayınevi, İstanbul 2006.

Hâfiz-1 Ebrû, Zübdetü't-Tevârîh, C. 1, 2, 3, 4, (Neşr. Seyyid Kemal Hâc Seyyid Cevadi), Vizâret-i Ferheng ve İrşad-i İslâmî, Tahran 1385.

Hamdullah Müstevfî-yi Kazvinî, Târih-i Güzide, (Çev. Mürsel Öztürk), TTK Yayınları, Ankara 2018.

Handmir, Tarih-i Habibü's-Siyer, C. 3, Kitabhane-i Hayyam, Tahran 1333.

Hasan-1 Rumlu, Ahsenü't-Tevarih, (Çev. Mürsel Öztürk), TTK Yayınları, Ankara 2006.

İbn Arabşah, Acâibu'l-Makdûr, (Çev. D. Ahsen Batur), Selenge Yayınları, İstanbul 2012.

İbnü'l-Esir, El-Kâmil Fi't-Tarih, C.XII, (Çev. Ahmet Ağırakça-Abdülkerim Özaydın), Bahar Yayınları, İstanbul 1987.

İdris-i Bitlisi, Heşt Bihişt, C.II, (Haz. Mehmed Karataş, Selim Kaya, Yaşar Baş), Bitlis Eğitim Tanıtma Vakfi, Ankara 2008.

Kadı Ahmed Gaffarî Kazvinî, Tarih-i Cihan Âra, (Nşr. Hasan Neraki), İntişârt-1 Kitabfuruşi Hafiz, Tahran 1343.

Keleş, Nevzat, "Van Gölü Havzası'nda Revvâdî ve Hezbânî Hâkimiyeti”, Tarihi ve Kültürel Yönleriyle Bitlis, C. I, (Editör: Mehmet İnbaşı, Mehmet Demirtaş), Bitlis Eren Üniversitesi Yayınları, Ankara 2019, s. 103-115.

Kemaleddin Abdurrezzak-i Semerkandî, Matla'-ı Sa'deyn ve Mecma'-ı Bahreyn, C. I/II, II/I, (Neşr. Abdul Hüseyin Nevâi), Pejuhaşkah-1 Ulum-i İnsanı ve Muta’alat-1 Ferhengi, Tahran 1383.

Konukçu, Enver, “Kara Koyunlular'1n Avnik Kalesi”, Prof. Dr. İsmail Aka Armă̆anı, İzmir 1999, s. 37-42.

Makrîzî, es-Sulûk li-Ma'rifeti Duvel el-Mulûk, C. V, (Thk. Muhammed Abdulkadir 'Atâ), Dâru'l-Kutubi'l-'İlmiyye, Beyrut 1997. 
Minorsky, V., “Uzun Hasan”, IA, C. XIII, MEB Yayınları, İstanbul 1986, s. 91-96.

Nizamüddin Şâmî, Zafernâme, (Çev. Necati Lugal), TTK Yayınları, Ankara 1987.

Sinclair, Thomas A., "Karakoyunlular Döneminde Ermeniler ve Bitlis'in Kürt Emirleri", Tarihi Kentler ve Ermeniler/Bitlis ve Muş, Ed. Richard G. Hovannisian, (Çev. Zülal Kılıç), Aras Yayınları, İstanbul 2016, s. 157-176.

Solmaz, Gürsoy, “Akkoyunlar’ın Kara Koyunlar’a Karşı Döşkaya Saldırısı”, A.Ü. Türkiyat Araştırmaları Enstitüsü Dergisi, S. 37, Erzurum 2008, s. 241-246.

Spuler, Bertold, İran Moğolları, (Çev. Cemal Köprülü), TTK Yayınları, Ankara 2011.

Sümer, Faruk, “Ahlat Şehri ve Ahlatşahlar”, Belleten, C. L, S. 197, Ağustos 1986, s. 447-494.

Sümer, Faruk, “Uzun Hasan”, DİA, C. 42, TDV Yayınları, İstanbul 2012, s. 261-264.

Sümer, Faruk, Kara Koyunlular (Başlangıçtan Cihan-Şah'a Kadar), C. I, TTK Yayınları, Ankara 1967.

Şerefhan, Seref-name, C. I, (Editor by Vladimir Veliominof-Zernof), St. Petersbourg 1860.

Şerefhan, Şeref-name, C. II, (Editor by Vladimir Veliominof-Zernof), St. Petersbourg 1862.

Şerefüddin Ali Yezdî, Zafernâme, (Çev. Ahsen Batur), Selenge Yayınları, İstanbul 2013.

Tacü’s-Selmani, Tarihnâme, (Çev. İsmail Aka), TTK Yayınları, Ankara 1999.

Taşkıran, Hasan, "Genel Hatlarıyla Ortaçağ ve Sonrası Bulanık'ın Coğrafyası ve Tarihi”, Bulanık/Kop (İnsan-Coğrafya-Tarih-Kültür), (Editör; İrşad Sami Yuca), Çizgi Kitapevi, Konya 2020, s. 169-185.

Taşkıran, Hasan, "Tabiiyetten Çatışmaya Akkoyunlu Timurlu İlişkileri”, I ğdır Üniversitesi Sosyal Bilimler Dergisi, S. 22, Nisan 2020, s. 305-347.

Tekindağ, Şehabeddin, Berkuk Devrinde Memluk Sultanlığg, İstanbul Üniversitesi Edebiyat Fakültesi Yayınları, İstanbul 1961.

Turan, Osman, Doğu Anadolu Türk Devletleri Tarihi, Ötüken Neşriyat, İstanbul 2009.

Uzunçarşılı, İsmail Hakkı, Anadolu Beylikleri ve Akkoyunlu, Karakoyunlu Devletleri, TTK Yayınları, Ankara 2011.

Ürekli, Muzaffer, “Celâyirliler”, DIAA, C.7, TDV. Yayınları, İstanbul 1993, s. 264-265.

Yahyâ Kazvînî, Lübbü 't-Tevârîh, (Haz. Seyyid Celaleddin Tehrani), Tahran 1314.

Yinanç, Mükrimin Halil, “Bitlis”, İ.A. C. II, MEB Yayınları, İstanbul 1979, s. 661-664.

Yinanç, Mükrimin Halil, “Celâyir”, İ.A, C. III, MEB Yayınları, İstanbul 1989, s. 64-65.

Yinanç, Mükrimin Halil, “Cihan-Şah”, İ.A., C. 3, MEB Yayınları, İstanbul 1945, s. 173-189. 